This preprint have been submitted for publication in Basin Research. Subsequent versions of this manuscript may have different content. If accepted, the final version of thismmanuscript will be available via the Peer reviewed Publication DOI link printed on this webpage. Comments and questions are welcomed. Please contact the first author Kabir Mainul ( r01smmk@abdn.ac.uk)

\title{
Seismic Characterization and Depositional Significance of the Nahr Menashe deposits: Implications for the terminal phases of the Messinian Salinity Crisis in the Northeast Levant Basin, Offshore Lebanon.
}

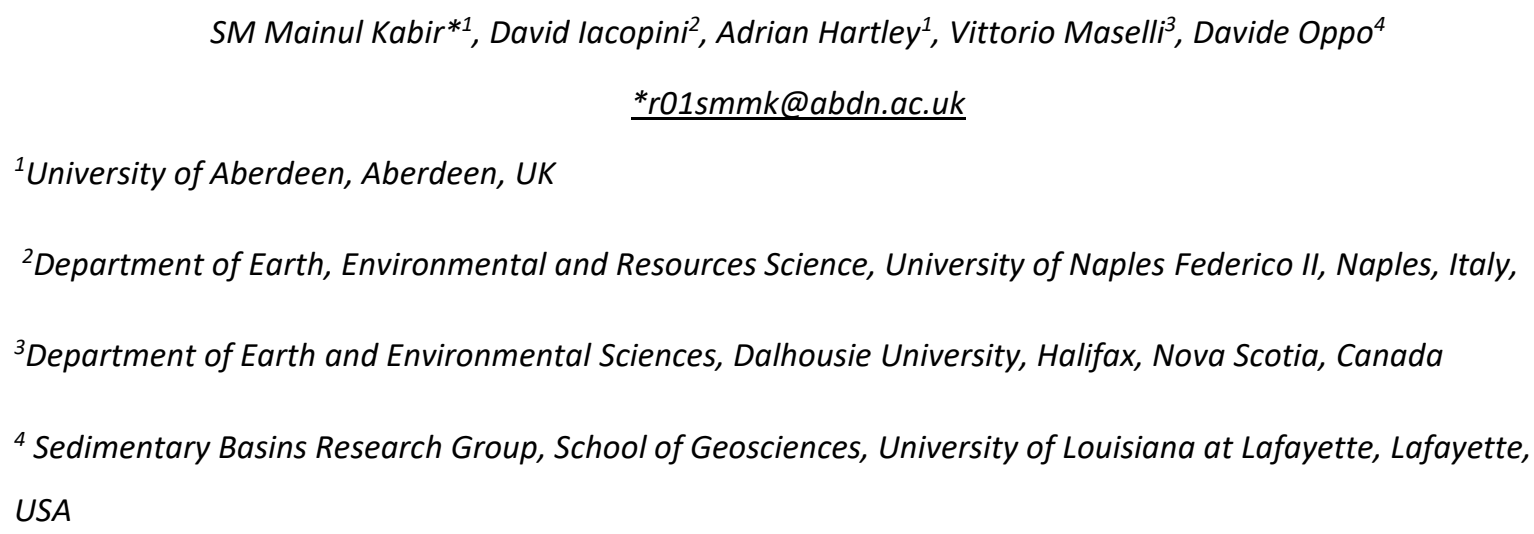
USA

Abstract

Over the last decade, there has been a resurgence of interest in the climatic and tectonic mechanisms that drove the Messinian salinity crisis (MSC) and the associated deposition of thick evaporites. The MSC represents an unprecedented palaeoceanographic change that led to a very short (c. $660 \mathrm{kyr}$ ) ecological and environmental crisis. However, across the Levantine offshore basin, the sedimentological nature of the top evaporitic units and the mechanisms that controlled the transition from a hypersaline evaporitic unit to brackish deposits (final MSC stage 3) are still disputed. Here, we re-evaluate the deposits associated with the terminal phase of the MSC, named in offshore Lebanon as the Nahr Menashe Unit (NMU). We describe the NMU seismic facies, characterize and map its internal seismic stratigraphy, and provide a new interpretation of its depositional environment, which persisted during the late Messinian and then evolved through a regional reflooding event. The base of the NMU overlies semi-circular depressions, randomly distributed linear marks and surface collapse 
features, which are indicative of a period of intense evaporite dissolution. The NMU seismic facies observed from the slope to the deep part of the basin support the interpretation of a layered salt-evaporite-sand depositional system subject to complex reworking, dissolution, deposition, and final erosion. A drainage network of valleys and complex tributary channels incising into the top NMU shows marked erosional characteristics, which indicate a dominant southwards sediment transfer following deposition of the NMU. This erosional drainage network formed due to the base-level fall associated with the last phase of the MSC. The base of the channel/valley network does not cut below the bottom of the Narh Menashe dissolution surfaces. The channel and valley network was subsequently infilled by layered sediments interpreted here to represent the post-MSC marine sediments deposited during reflooding. Our analysis challenges the previously proposed fluvial nature of the NMU and instead suggest that it is a mixed evaporite-siliciclastic unit deposited in a shallow marine or lacustrine environment during the tilting of the offshore Lebanese basoin. Only subsequently did the NMU experience a rapid erosional event followed by swift burial of transgressive/high-stand sediments.

Key words : Seismic facies, dissolution, inscise, passive infill, Messinian,Levant

\section{INTRODUCTION}

The isolation of the Mediterranean Sea from the Atlantic Ocean during the MSC ( Ryan, 1978) led to the rapid deposition of halite dominated evaporite sequence (Roveri et al., 2016) up to $2 \mathrm{~km}$ thick in the deeper parts of the Eastern Mediterranean region (Haq et al., 2020; Ryan \& Cita, 1978, Fig 1 a). Despite a long research history (Haq et al., 2020; Hsü et al., 1973; Lofi et al., 2011; Netzeband et al., 2006a; Roveri et al., 2014) the scientific community is still divided on how and why this enigmatic event ended (Andreeto et al., 2021; Haq et al., 2020; Meilijson et al., 2019 Roveri et al., 2014). This uncertainty is also due to significant variations in the magnitude and duration of the evaporite deposition event across the basins (Camerlenghi et al., 2020). As a consequence, the Messinian deposits record different tectonostratigraphic histories in different sub-basins of the Mediterranean (see Roveri et al.,2014; Andreetto et al., 2021). From a seismic stratigraphic perspective, three distinct seismic units have been identified in the Western Mediterranean Basins (Lofi et al., 2011), whereas in the Eastern Mediterranean region one single Mobile Unit (MU) (Lofi et al., 2011; Netzeband et al., 2006a; 
Roveri et al., 2014), containing the alternation of high amplitude-coherent reflectors and seismically transparent layers has been recognized (Fig. 2 a). In the Levant area, where the Mobile Unit (MU) reaches its maximum thickness, six sub-units have been recognized using a velocity model for the transparent and reflective layers (Feng et al., 2016; Gvirtzman et al., 2013). In offshore Israel, Feng et al., (2016) presented a well log interpretation model showing that the transparent units have distinctly higher velocities $(4200-4400 \mathrm{~m} / \mathrm{s})$ than the reflective parts $(3800-4000 \mathrm{~m} / \mathrm{s})$. They interpreted the higher velocity packages as thick halite layers with intra-salt reflective horizons, with lower velocities considered to represent a mixture of salt and clastic deposits. Other workers (Cartwright \& Jackson, 2008; Gradmann et al., 2005) suggested that the intra-salt reflective layers are composed of anhydrite or gypsum. Gvirtzman et al., (2017) used gamma ray and resistivity logs together with seismic data to define a new package (named Unit 7) which forms the uppermost unit of the Messinian evaporites bounded between two key horizons, the Intra Messinian truncation surface (IMTS) (Gvirtzman et al., 2017) and the Top Erosive Surface (TES) (sensu Madof et al.,2019). They interpreted this unit to comprise alternating anhydrite, sand, and clay layers. In the Lebanese Levant Basin, information regarding the lithological nature of the termination of the MSC is limited due to a lack of publicly available well data and core material. Consequently, the stratigraphic framework and the interpretation of the MSC event in the Lebanese section of the Levant basin still exclusively dependent on geophysical methods (primarily interpretation of seismic reflection data). Across the central north Levantine basin the supra evaporitic deposits above the IMTS have been mapped and named by Madof et al.,(2019) as the Nahr Menashe deposits. For reference, Madof et al (2019) renamed the IMTS as Intermediate Erosion Surface. Given its supra-evaporitic position the Nahr Menashe has been interpreted to be late Messinian in age, equivalent to the upper part of stage 3 of Roveri et al., (2014), to the Unit 7 proposed by Gvirtzman et al., (2017) in Israel or Unit 3.2 in the new stratigraphic scheme proposed by Meilijson et al., (2019). The interpretation proposed for these top Messinian deposits mapped across the central north levant and the Cyprus basin area varies from fluvial deposits subject to subaerial exposure (Madof et al., 2019), to shallow marine deposits with subaqueous dissolution and a truncation surface at the base ( Gvirtzman et al., 2017; Kirkham et al., 2017). In this paper, using a newly released 3D seismic dataset, we reassess the stage 3 of the MSC (sensu Roveri et al 2014) in the north-eastern Levant Basin, with respect to the description and interpretation of the top Messinian deposits (Unit 7 or 
Unit 3.2 equivalent). For simplicity, the seismic package defining the Nahr Menashe deposits will here be named the Nahr Menashe Unit (NMU). Here, we describe and discuss for the first time the distinctive seismic facies assemblages that characterise the internal stratigraphy of the NMU. We then discuss the nature of the erosive features affecting the base of the NMU and extend our interpretation to unravel the paleodepositional history of the NMU. Our results shed new light on the terminal phases of the MSC and provide improved constraints on this widely debated period in the history of the Mediterranean Sea.

\section{GEOLOGICAL SETTING}

The study area is located in the East Mediterranean Sea, Levant Basin, offshore Lebanon (Fig. 1b). It is bordered by the Latakia Ridge to the northwest, the Levant Fracture System (Dead Sea Transform Zone) to the east, the Eratosthenes Seamount to the west, and the edge of the Nile-delta deep-sea cone to the southwest (offshore Israel). The Levant Basin and surrounding area have undergone a long and complex tectonic history. This includes Permian to Early Jurassic polyphase rifting (Gardosh et al., 2010; Garfunkel, 1998; Petrolink et al., 2001) linked to the opening of the Neotethys Ocean (Nader et al., 2018), a passive margin development in the Late Jurassic, followed by plate collision and associated subduction in the Late Cretaceous that created the Latakia Ridge as a part of the Cyprus Arc System (Robertson et al., 2012) with ophiolite emplacement and orogenesis in the Late Maastrichtian (Hawie et al., 2013; Hsü et al., 1973; Petrolink et al., 2001; Robertson, 1998). Across the Eastern Mediterranean and its marginal zones, the late Cretaceous collision (which continues to the present day) led to a topographical inversion of early Mesozoic normal faults and sets of asymmetric folds along the basin margin (Syrian arc structures, (Garfunkel, 1998; Hardy et al., 2010). In the late Miocene, as a response to the opening of the Gulf of Aden and Red Sea (Beydoun, 1999; Hawie et al., 2013) compression moved to to the onshore Dead Sea Transform ( Kartveit et al., 2019) along the Levant fracture System and also reactivated the Latakia Ridge as a sinistral transpressional feature (Hall et al., 2005). After the Messinian, as a consequence of transpressive movement along the North - South Levant fracture system driven by the westward migration of the Anatolian plate (Hawie et al., 2013), the eastern margin of the Levant basin become progressively uplifted (Gvirtzman et al., 2013) from the Miocene to late Pleistocene (Ghalayini et al., 2018; Matmon et al., 1999). 
A stratigraphic scheme for the northern Levant Basin based on well data has yet to be published, therefore correlation has been guided using information from the southern Levant Basin (Gvirtzman et al., 2013; Meilijson et al., 2019). Sedimentary sequences beneath the Messinian salt deposits are composed primarily of carbonate-siliciclastic sediments sourced from both the proto-Nile delta (Gardosh \& Druckman, 2005; Ghalayini et al., 2018; Kartveit et al., 2019) and deep canyons along the Levant Margin (Druckman et al., 1995), which cumulated in a deep basin depositional environment from Oligocene to Early Middle Miocene times. Towards the end of the Miocene (within the Messinian), the closure of the Gibraltar Strait isolated the Mediterranean Sea from the Atlantic, resulting in the deposition of an approximately $2 \mathrm{~km}$ thick multilayered evaporitic sequence across most of the Levant Basin until re-establishment of a marine connection to the Atlantic (Haq et al., 2020). At the terminal stage of the MSC, a seismically detectable reworked evaporite is regarded as the latest expression of Messinian deposits in the Levant basin and is named the Nahr Menashe deposits (Madof et al., 2019), which preludes a progressive return to normal marine conditions again.

Across the Levant basin, Feng et al., (2016) divided the Messinian evaporites into six Intra Messinian seismic units (from deep to shallow) named ME1, ME2, MC1, ME3, MC2, and ME4 (Fig. 2a), which correspond to the units 1 to 6 described by Gvirtzman et al. (2013). These seismic units are stratigraphically confined by the base of the salt or BS (Lofi et al., 2011) and the Intra-Messinian Truncation Surface (IMTS) by Gvirtzman et al., (2017) and Karveit et al., ( 2019), called also TES or TS (Feng et al., 2016; Lofi et al., 2011) which could also be correlated with the traditional M reflection (Vidal et al., 2000). The extent of IMTS in the Eastern Mediterranean has been widely mapped and observed in the Cyprus, Latakia, and Levantine basins (Bertoni \& Cartwright, 2007; Feng et al., 2016; Gvirtzman et al., 2017; Haq et al., 2020; Kartveit et al., 2019; Kirkham et al., 2020; Lofi et al., 2011). This truncation surface has been variously interpreted both as a product of subaerial exposure and erosion linked to relative sea-level fall (Bertoni \& Cartwright, 2007; Kartveit et al., 2019), combined with a tectonic shortening related to the Cyprus Arc subduction (Maillard et al., 2011), or due to dissolution process as a result of freshening of the water column and the development of a stratified deep water basin (Gvirtzman et al., 2017). Recently, Kirkham et al., (2020) proposed an alternative model where the IMTS truncation is interpreted as the result of a major phase of 
syn-Messinian deformation that uplifted the salt progressively across the thermocline and into the thermally under-saturated epilimnion where it was dissolved. During Plio-Quaternary times, $1.5 \mathrm{~km}$ of fine-grained siliciclastic sediment was deposited over the evaporites (Kartveit et al., 2018). Sediment was sourced from both the Nile-delta (Niyazi et al., 2018, Zucker et al.,2021) and the Levant basin margin (Gardosh et al., 2010) with a basinward progradation (Lazar et al., 2016) observed across all the Levantine area. From a structural viewpoint, the interplay between differential sediment loading (Netzeband et al., 2006b), inland uplift ( Gvirtzman et al., 2013), and basin tilting (Cartwright \& Jackson, 2008; Gradmann et al., 2005) affected post Messinian deposits by triggering salt movement (Evans \& Jackson, 2019; Oppo et al., 2021) and slope instability as indicated by episodic submarine mass wasting (Gvirtzman et al., 2015; Kartveit et al., 2018). At a regional scale, the northeastern Mediterranean was also subject to collisional tectonics ( Ghalayini et al., 2014; Hawie et al., 2013) producing crustal shortening along the basin margin and accretionary loading in the south (Maillard et al., 2011). The major extensional faults affecting the post evaporitic deep water deposits nucleate from the mobile salt and appear to be halokinetically generated rather than recording a regional tectonic compressive event (Evans \& Jackson, 2019; Oppo et al., 2021) suggesting that intra salt layer movement was initiated just after deposition of Pliocene sediments (Gvirtzman et al., 2013).

\section{DATA AND METHODOLOGY}

Approximately $3067 \mathrm{sq} \mathrm{km}$ of merged Post-Stack Time Migrated 3D seismic cubes and six 2D seismic lines from Petroleum Geo-Services (PGS) were used in this work across the northern Levant Basin (Fig. 1 b). All data were acquired and reprocessed through time with the same acquisition parameters as a part of the Lebanon MC 3D project. The final stack data are represented as zero phased data and displayed with SEG reversed polarity (Brown, 2004). On the seismic sections, hard kick reflectors show a downward increase in acoustic impedance and are represented by a red colour (trough) whilst a black colour (peak) is associated with a relatively soft event indicating a downward decrease in impedance (Fig. 2b). As in the Lebanon offshore basin there are no publicly released well data to date, stratigraphic correlations (including their nomenclatures) of the different units are based on previous studies (Cartwright \& Jackson, 2008; Gardosh \& Druckman, 2005.; Gradmann et al., 2005; Hawie et 
al., 2013; Netzeband et al., 2006b). The dominant frequency (F) of the section of interest (below the seabed) ranges between 40 and $75 \mathrm{~Hz}$. The average P-wave velocities adopted for seawater is $1500 \mathrm{~ms}^{-1}$, while for the subsurface velocities we did refer to Haq et al., (2020) with a velocity of $3200 \mathrm{~ms}^{-1}$ for the investigated interval below the seafloor down to the Top Messinian and a velocity of $4200 \mathrm{~ms}^{-1}$ for the MU. Using these end-member velocities and frequencies, we estimate a vertical resolution (defined as tuning thickness, $\lambda / 4=v / 4 F$, being) observed in the shallow Neogene deposits of $5 \mathrm{~m}$ at the seafloor and 20-26.5 $\mathrm{m}$ for the units below.

In this study, the base of Messinian Salt (BS), the Base of the Nahr Menashe (BNM), Top of the Nahr Menashe (TNM), and Sea Bed surfaces have been mapped (Fig. 3a, b, c) using initially a $10 \times 10$ inline and crossline increment (equivalent to a $125 \times 125 \mathrm{~m}$ grid) then interpolated using converging interpolation algorithm down to a single inline and crossline spacing. Within the NMU more focused surfaces have been instead mapped using a 1x1 mapping increment $(25 \times 25 \mathrm{~m})$. Considering the focusing effect of Kirchhoff migration (Brown, 2004), the horizontal resolution on the seabed mapped surface can be considered equivalent down to the line spacing (Lebedeva-Ivanova et al.,2018).

In this paper, we interpreted the seismic data to map key stratigraphic horizons: top salt (TS) and base NMU, top NMU, and the first package draping above it. Thickness surfaces have been derived for both the NMU and the post-NMU package unit above. Post-stack seismic attributes Variance (Chopra and Marfurt, 2007) and Root Mean Square (RMS) amplitude have been calculated (Barnes, 2016). Frequency decomposition and an RGB blended view of three selected frequency spectra (Henderson et al., 2008) using GeoTeric have been used to highlight channel and valley features. Finally, a qualitative seismic facies analysis approach using the character of a group of reflections involving amplitude, abundance, continuity, and configuration of reflections have been applied with the aims of characterizing the seismic facies response of the NMU.

\section{Results: Nahr Menashe Deposits in the Levant Basin}

The uppermost deposits of the Messinian evaporites in the northeastern Levant basin, are bounded by two seismic reflectors both characterized by hard kicks. The Top of the Nahr 
Menashe is here called the Top Nahr Menashe (TNM), whilst the base of this unit is referred to as the Base Nahar Menashe (BNM) which chiefly corresponds to the Intra Messinian Truncation Surface - IMTS (Gvirtzman et al., 2017). The thickness of the NMU varies to a maximum of $180 \mathrm{~ms}$ (twt) on the southern and deepest part of the basin, thinning to the single reflector resolution ( the top and bottom reflectors now merging) along the shelf-slope area of the basin (Fig. 4). Within the NMU, we can observe variable frequencies of internal reflections having moderate to strong amplitudes. Some repetitive (maximum 2 to 3 cycle), coherent, strong amplitude, and semi-continuous seismic packages are observed in the southern and central part of the deep basin although numerous erosive features and postdepositional faults and folds have extensively modified their internal reflections. The internal seismic expression (strong amplitude, high frequency, and semi-continuous) of the NMU have strong similarity to the intra-halite reflectors interpreted as clastic units by Feng et al (2016) (across unit 4 to 6 of the $\mathrm{MU}$ ) rather than the overlying deepwater Plio-Quaternary sequences (Kartveit et al., 2018) and will be described later in detail. The BNM is affected by NNE-SSW trending compressional anticlines (Fig. $3 \mathrm{~b}$ ) that are up to $18 \mathrm{~km}$ long and $3 \mathrm{~km}$ wide both in the northwestern and in the southern central part of the dataset.

\subsection{Top Surface of Nahr Menashe (TNM)}

In the northern Lebanon Basin, detailed mapping of the TNM produces a surface characterized by erosive channel/valley features which merge southwards to create an overall north to south directed drainage network with intervening residual highs (Fig. 5). The principal erosive structures have widths from 1 to $3 \mathrm{~km}$ and depths of tens to hundreds of meters (maximum $60 \mathrm{~ms}$ twt) and are referred to as seismic valley features (Fig. 4). Detailed mapping of these structures shows that the largest valleys comprise a series of nested erosional features that appear to stack laterally to form a composite basal erosional surface (Fig. 6b). In the northwest of the study area, the drainage network is characterized by smaller erosional features (channels) that have a width of a few hundred metres and form a welldeveloped tributary drainage pattern up to $50 \mathrm{~km}$ wide which extends for up to $500 \mathrm{~km}$ along a northeast to southwest direction.

The principal valley-type features run close to parallel to the Levant margin. In places, erosional drainage networks are modified by subsequent salt movement (Fig. 6 a, b ). Salt 
structures can be imaged through semblance image analysis or spectral decomposition (Fig. $5 b)$, which show that the salt reshapes or perturbates the main channel system geometry (Fig. 5b, white arrows).

A detailed analysis of the TNM reflector indicates that the top surface of this unit is not always defined by a distinctive single reflector but often by composite erosive reflectors (Figs. 6 b \& c).

\subsection{Basal Surface of Nahr Menashe (BNM)}

The BNM reflector is characterized by a hard kick and appears very well preserved, remarkably smooth, and displays a more continuous reflectivity than the TNM. Overall, the surface appears mostly conformable except where it has been modified by the postdepositional salt movement to produce contractional symmetric and asymmetric folds (Figs $6 \mathrm{a}, \mathrm{b}$ ) of 50-150 ms (twt) dimension or it truncates the deformed salt structures (Fig 9b). The basal surface does not appear to be affected by the incised valleys or incisional drainage networks affecting the NMU ( Fig 6 a, b \& c). The mapped BNM surface displays scattered circular and semi-circular depressions that often appear as isolated linear expressions eroding this surface (Fig. 7, 8, and 9) and are described in detail below.

\subsubsection{Circular Depression Type Seismic Features}

Numerous circular, semi-circular to elongate, randomly distributed depressions are observed affecting the BNM surface. The depressions are 50 to $700 \mathrm{~m}$ in diameter, up to a maximum of $60 \mathrm{~ms}$ (twt) in depth, occasionally clustered or isolated, and often bordered by linear erosive features (Fig. 7). Examination of the seismic reflections defining the deposits filling the circular features indicate that the material drapes or has slumped into the depression. The features observed are suggestive of dissolution and collapse mechanisms associated with underlying salt bodies followed by a draping and/or passive collapse of material into dissolution hollows. Similar structures have also been described across the equivalent IMTS regional erosive surface in offshore Israel by (Cartwright et al., 2012) and were interpreted as being generated by salt dissolution. Significantly, the distribution of dissolution features does 
not show any relationship with the drainage network described above on the TNM (Figs. 9 $a, b)$.

\subsubsection{Linear Depression Type Seismic Features}

282

Linear depression features 100 to $5000 \mathrm{~m}$ in length, $20-80 \mathrm{~m}$ wide and up to a maximum of $20 \mathrm{~ms}$ (twt) in depth which initiate and terminate abruptly (truncating underlying reflectors) are systematically observed and mapped across the BNM (Fig. 7) and within the internal reflectors of the NMU (Fig. 8). These linear depression features imprinted on the basal surface and intra Nahr Menashe reflections do not show any preferred orientation (Figs. 7 and 8). In some cases, in cross-sections, these features appear as small collapse structures underpinned by bright anomalies or affected by small pipe structures (see blue arrows in Fig 7).

\subsubsection{Collapsed Surface or Passive Collapsing of BNM}

The linear features described above may form zones of weakness along erosional or what appear as dissolution features which in places are further exploited by faults leading to collapse structures (black arrow, Fig. 9). These passive fault collapse features are 150-800 m long, a few tens of metres in width, and 30-50 ms (twt) deep (Fig. 9). The collapse of the BNM also affects the overlying Nahr Menashe Unit which tends to passively infill into the underlying area. This dissolution process has been ascribed by different authors to overburden deformation (Cartwright et al., 2001; Jackson et al., 1994; Jackson \& Hudec, 2017) intra-layer faulting (small scale), fracturing, or cave collapse (Zeng et al., 2011).

\subsubsection{Fluid Leakage}

301

Flanking the dissolution features and the collapsed areas of the BNM reflector, we observe, vertical or sub-vertical pipe-like structures that initiate from the BNM and cross through the NMU producing a clear downward deflected v-shaped depression that dies out downwards (Fig. 9 b, blue arrow). These features are up to $120 \mathrm{~ms}$ (twt) high and 50-90 meters wide. We interpret these features to form as a result of the interplay between dissolution mechanisms and fracture nucleation that exploit collapse structures produced by the salt movement. Dewatering of the top salt unit produced fluid migration along fractures affecting the TNM 
collapse from above (Fig 9 b). Similar discordant pipe-like structures are also documented from the salt unit of the Santos Basin, Brazil (Rodriguez et al., 2017), the Fort Worth Basin (carbonate rocks), Texas (Hardage et al., 1996), and the Persian Gulf (Burberry et al., 2016) where they are similarly interpreted as dissolution related leakage pipe breccias.

\subsection{Top Nahr Menashe and Post Messinian Units.}

The first laterally continuous marker horizon (pink reflector in Fig 10) referred to as the top marker horizon that can be mapped above the NMU, appears as a reflection boundary showing a mappable continuity and internal coherency. This surface can be mapped across the entire study area above the TNM except in places affected by recent structural features such as the Lebanon Fracture system, Latakia Ridge, and crestal faults. The package between the TNM and the top marker defines a seismic package that is finely layered internally. The complex drainage patterns that incise the NMU appear passively infilled as indicated by reflectors that drape or onlap the valley vargins (Figs.10 a, b, and c ). Truncation or termination of the underlying reflections of this package against the top marker horizon (pink horizon) indicates that this horizon represents at least in part, an erosional surface.(figure 11). The top marker horizon (pink reflector) is also conformable with overlying refleectors interpreted to represent deep water deposits (Fig 10 and 11). The thickness map of this package (between the TNM and the top marker) shows the clear infilling character of the package (Fig. 12). The map shows the average twt thickness of the TNM-top marker unit varies between 40 to $160 \mathrm{~ms}$ across the basin, with maxima in the deepest valley fill section in the central-southern part of the study area (Fig 12). The package is stratigraphically lower than the regional 1.8 Ma horizon interpolated using the information by Kirkham et al. ( 2020).

\section{Seismic Facies Within the Nahr Menashe}

Detailed seismic and attribute mapping of the Top Messinian Unit across the offshore Lebanon basin has allowed the recognition of several internal seismic facies characterizing the NMU. Six distinctive seismic facies (Table 01) have been recognized and categorized based on a seismic facies approach i.e. internal reflection continuity, amplitude, thickness, and coherency. The facies suggest a strong lateral variation in the internal character of the top 
unit. All facies are affected by fracturing, faulting, and different amounts of dissolution related to the latest deformation/salt tectonic event (Oppo et al., 2021).

This facies comprises $2 / 3$ cycles (cycle here defined as a peak-through-peak triplet) of coherent seismic packages characterized by parallel, internal, semi-continuous to continuous reflections showing strong reflectivity (Fig. 14). This seismic pattern has been mapped as a $120-180 \mathrm{~ms}$ (twt) thick package, $0.5-3 \mathrm{~km}$ in length, and is frequently fractured and contains intra-layer faulting. This facies is observed only where the NMU is at its thickest and adjacent to the erosive valley walls. Internal reflectors of the coherent packages are often truncated by high-angle valley walls (dipping up to 45 degrees in some places, figures 14- 1A). From a seismic textural viewpoint (geometrical internal character of the facies), the reflection pattern (strong amplitude and frequency) has a close resemblance to the underlying clastic part of the Messinian salt and is distinctly different from the overlying Plio-Quaternary highfrequency low reflection pattern (Fig. 15 \& 16). Within this facies, we recognize three different post-depositional modification subclasses with external sheet geometries (Fig. 14, feature $1 \mathrm{~A})$ :

Subclass $1 \mathrm{~A}$ conformably overlies the BNM where internal reflections are defined by strong cyclic and continuous reflections that are mostly undeformed (no intense fracturing, faulting, or collapse). To investigate the seismic morphology of the continuous reflectors, three horizons were mapped in detail (Fig. 8). Each horizon (Fig. 8) displays features characteristic of dissolution such as linear, semi-circular depressions (white arrow in Fig. 8) which occasionally terminate against faults and internal fractures and are strikingly similar to the morphological features observed on the BNM. In most cases, faults/fractures die out within this package (Fig. 16) suggesting this package defined by sub-class facies $1 \mathrm{~A}$ has a brittle behaviour. These linear dissolution marks $150-400 \mathrm{~m}$ wide and 500 to $5000 \mathrm{~m}$ in length are mapped within intra layers and decrease in intensity and number upwards (bottom to top horizons). Some of these features observed in the BNM (Fig 7a) are linked to small vertical features which do not cut the entire NMU and show amplitude anomalies suggesting fluid movement from lower salt units through the BNM. On the surface they coincide with circular or linear erosive marks, with no displacement, which are here interpreted as resulting from 
post-depositional diagenetic changes due to the movement of undersaturated brines from lower salt units through the BNM, coupled with internal deformation associated with intraformational gravity gliding.

Subclass $1 \mathrm{~B}$ is also characterized by coherent cyclic seismic packages but affected by strong fracturing and intense faulting crossing the NMU (Fig. 14, see seismic feature 1B). The BNM below this subclass appears broken, collapsed, or faulted and associated with cross stratal fluid/brine migration discussed for the subclass $1 \mathrm{~A}$.

The third subclass of the coherent cyclic packages is characterized by a seismic package that displays discontinuous reflections, affected by crestal faults and bordered by dip slopes controlled by salt intrusion (Fig $14-1 \mathrm{C}$ ). They represent the equivalent of facies $1 \mathrm{~A}$ and $1 \mathrm{~B}$ but strongly deformed by the salt intrusion

\section{Seismic Facies 2}

This mounded seismic facies is characterised by a strongly eroded and reworked package where a soft kick is coupled to the hard kick that defines the base of the Nahr Menashe. The thin package appears chaotic at the top of the Nahr Menashe and shows sub-circular elongate mound-shaped seismic features (Fig 14-2).

\section{Seismic Facies 3}

In the southwestern part of the study area, the NMU appears completely deformed, with both internal and external reflectors affected by the combined effects of fluid escape, lower boundary collapse, and intralayer faulting and fracturing (Fig 14). Internal reflections are broken. Numerous $\mathrm{u} / \mathrm{v}$ shaped channels further modify the top surface of this unit. The orientation of these channels appears unrelated to underlying salt structures (Fig 4) and are mapped in areas where the entire thickness of the entire halite unit is preserved. Occasionally, the internal reflection of the top part of this unit shows a tendency for downlap to the BNM boundary strongly deformed. The broken nature of internal reflections suggests the relatively brittle behaviour of the materials. The internal seismic features suggest here the NMU may represent a residue of redeposited material affected by dissolution and deformation. 
Seismic facies 4 has a smooth continuous top boundary but the internal reflections appear chaotic as the individual reflections/horizons cannot be traced. It is mapped in the central part of the study area where it is preserved in between erosive valley/channel networks affecting the TNM. This unit has a uniform thickness ( $~ 80 \mathrm{~ms}$ twt) with an undisturbed top boundary. The lower boundary displays collapsed features and the sediments from the upper part of the unit drape or fall into the available accommodation spaces (Fig 14-4), generating discontinuous and broken internal reflectors producing an overall chaotic pattern of the internal reflections within this facies.

Seismic facies 5

411

In areas where the TNM drainage network appears strongly erosive, the NMU appears to be thin (sometimes below seismic resolution) and almost unaffected by deformation but characterized by residual mound features that overlie fluid pipes that breach the BNM surface. This seismic facies has a sheet-like geometry with draping to pinch out type stratigraphic signature (Fig. 14), due to the gradual reduction in thickness of the NMU. In some specific places, the TNM merges with the BNM, and the internal reflections are not or poorly distinguishable individually.

Seismic Facies 6

Along both the flanks of Latakia ridge and along the slope of the Lebanon basin margin where post-Messinian compressional fault re-activation is well expressed (Fig. 4), the seismic units are characterized by seismic packages that either form a series of blocks that preserve internally coherent reflection packages but are bounded by faults or, show areas with a chaotic pattern, where reworked/re-deposited facies are present. Within the blocks, internal reflections approximately follow the dip direction of intra-salt stratigraphy (Fig 14). This seismic facies is interpreted to represent mass transport deposits related to slope failure associated with the uplift of the Latakia Ridge or basinward subsidence and landward uplift of the Lebanese-Levant margin. 


\section{Discussion}

The magnitude and duration of the MSC event including the sea level drawdown varied significantly throughout the Eastern Mediterranean where Messinian deposits record distinct tectonic and stratigraphic histories across different mini-basins (Butler et al., 1995; Haq et al., 2020; Roveri et al., 2014). In the north-eastern Levant Basin, we have analysed seismic reflection data to characterise the nature of the terminal stage of the Messinian Salinity Crisis. To place our observations into context and to interpret the nature of reflooding of the basin it is important to reconstruct the termination history of the MSC in the Levant Basin.

\subsection{Base of Nahr Menashe}

Across the entire Levant Basin and the Eastern Mediterranean in general, the base of the $\mathrm{NMU}$, has been interpreted as an erosional surface because of its discordant nature (up-dip termination) and the relationship with NW dipping intra-evaporite layers (Bertoni \& Cartwright, 2007; Kartveit et al., 2019; Ryan et al., 1973). In our mapping, it coincides with the IMTS. Using seismic and well data (Aphrodite-2,Myra-1, Sara-1) from offshore Israel (Southern Levant Basin), Gvirtzman et al. (2017) interpreted this surface as a truncation surface generated by subaqueous dissolution. They proposed a horizontal chemocline model (halite saturated hypolimnion and under saturated epilimnion) for stratified water column (fig 4 of their paper), to explain the origin of this surface and referred to it as the IMTS. Recently, Kirkham et al., (2020) mapped the extensive truncation relationship of the Base of the NMU as the IMTS at the base to the MU in offshore Israel (map $1 \mathrm{~b}$ from their paper), supporting the dissolution model and separating marginal and deep basin environments where thermocline diffusion was responsible for dissolving the top of the salt (fig 07 their paper).

In this paper, we note that the BNM represents the second strongest acoustic reflection after the sea bed (Fig. 2b) and coincides with the IMTS, thus allowing precise, continuous mapping of the surface across the entire dataset. In our study area, the intra-evaporite layers of the NMU appear roughly concordant and undeformed with respect to the BNM, across the deep basin, but appear discordant or truncated toward the margin or where NMU is deformed by faulting, folding, ductile flowage, or structural highs (Figs. 15 \& 16). The BNM mapped surface, 
in the deeper part of the basin, displays strong dissolution features similar to those observed by Kirkham et al. (2020), indicating that dissolution processes had acted on this surface prior to deposition of the NMU. These observations suggest that a laterally heterogeneous model should be adopted for the interpretation of the BNM surface across the basin. In the deeper part of the basin, a subaqueous dissolution process controlled surface development whilst erosional processes prevailed along the basin margin and across other elevated parts of Eastern Mediterranean such as the Herodotus and Eratosthenes seamounts and the Latakia Ridge ( Kartveit et al., 2019). Also, from a regional perspective, at this stage of the Messinian Crisis, sea level is likely to have been close to its lowest point (stage 2) due to isolation related to the Sicily gateway (Camerlenghi et al., 2020; Haq et al., 2020; Roveri et al., 2014) triggering extreme evaporation, extensive evaporite precipitation and which at a certain point exposed some parts of the basin margin to subaerial erosion. We suggest therefore that following the consensus model (Roveri et al., 2014) the BNM may represent the boundary between stage 2 and stage 3 of the Messinian Salinity Crisis when halite saturated brines were transformed to gypsum saturated brines and/or brackish Lago Mare conditions (Gvirtzman et al., 2017) which were deposited above the BNM (Hilton, 2001; Kartveit et al., 2019). In summary, the seismic geomorphic features displayed by the BNM suggest that the laterally heterogeneous nature of this surface is related to strong dissolution (Gvirtzman et al., 2017) coupled with marine regression, subaerial erosion along basin margins (Bertoni \& Cartwright, 2007), and waveerosion (Bache et al., 2012) on intra-basinal platforms (Micallef et al., 2019).

\subsection{Interpretation of the Seismic Facies in the Nahr Menashe Unit (NMU)}

As the upper part of Unit 7 (Meilijson et al., 2019) the Nahr Menashe deposits (Madof et al., 2019), are considered to represent the terminal deposits of the MSC. In our data set, the NMU displays a very variable seismic expression and thickness from a maximum thickness of 180 ms (TWT), with $2 / 3$ cycles of coherent and strong seismic reflectors parallel to both top and bottom surfaces, to places where it shows evidence for strong dissolution at the base and within some layers. The seismic facies mapped across the NMU in the study area display a range of stratigraphic and structural characteristics that vary depending on the structural and depositional context within the Lebanon Basin (deep to marginal basin). In the deeper basin where the NMU is better preserved (between erosive valleys) and unaffected by intrusive salt 
bodies, clear, distinctive strong cyclic and continuous reflections are present and mappable (Facies 1a). These are similar to the intrasalt reflection character described by Feng et al. (2016) and Gvirtzman et al. (2017) below the IMTS (here equivalent to BNM), suggesting the Nahr Menashe stratigraphy likely represents a multi-layered system of thicker salt-evaporite units sandwiching thinner sand and shale units. In areas of salt movement, the NMU is deformed by well-defined faults and fractures that are confined within the unit (facies $1 \mathrm{~b}$ ). In areas unaffected by salt intrusion, or parts of the deeper basin, the NMU is thin or less layered (Facies 4 and 5). In some cases, the BNM and the units immediately above are affected by sub-circular, elongate, mound-shaped (Facies 2) seismic features similar to those observed by Stafford et al. (2008), Chiesi et al. (2010), and Rodriguez et al. (2017) and interpreted as gypsum-dominated karst or residual mounds from areas strongly affected by near-surface dissolution. We interpret these latter facies to represent brecciated karst (gypsum/limestone) generated by the dissolution of soluble salt (Jaworska \& Nowak, 2013; Kyle \& Posey, 1991). In the remnant area of the deep basin affected by salt intrusion or across the deformed shelfslope area (Latakia Ridge and Levant fracture), collapse and crestal fault systems associated with salt dissolution affected the units across and beyond the NMU (Facies 1c and 6). Those facies are characterized by poor internal stratigraphy suggesting that the NMU internal unit has been strongly re-worked and re-deposited by later compressive tectonic events (e.g. Ghalayini et al., 2014; Hawie et al., 2013) making the clear characterization of their original internal stratigraphy difficult. The range of seismic facies characteristics documented here brings into the question the interpretation of the $\mathrm{NMU}$ as an offshore equivalent to outcrop analogues of non-marine sedimentary packages described from the eastern Mediterranean (e.g. Eosahabi deposit, offshore Libya - Bowman, (2012) or the Abu Madi, offshore Egypt Leila et al.2020).

\subsection{Interpretation of the Top Nahr Menashe (TNM) Erosive Features}

Our 3D mapping highlights a complex drainage system characterized by numerous channel and valley features (first described by Madof et al 2019), which incise the top of the unit but do not show erosion down to or below the basal surface (BNM). The complex drainage appears passively infilled by a finely layered package of a different character, as suggested by the reflectors which appear to drape the valleys in the NMU. This observation suggests that 
the maximum base-level fall during late Messinian times did not drop below the BNM level and that erosion occurred after the deposition and/or redeposition of the Nahr Menashe deposits. The complex drainage pattern represents therefore the final erosive event of a more complex depositional history recorded by the NMU.

\subsection{Deformation of Nahr Menashe Unit}

From a structural point of view, the NMU appears to have been affected by a postdepositional deformation event which triggered faults of various geometries and sizes. As described in facies 1c (Fig 14), some late faults are related to salt remobilized or intruding across the overburden as indicated by the crestal faults nucleating from the intrusive bodies and affecting the entire overburden (Oppo et al.,2021). Similar fault structures appear diffused around the Latakia Ridge where the recent regional tectonic activity has overprinted earlier events (Ghalayini et al., 2014). In other cases, as shown by facies 6 (Fig 14 and Fig 17(, the NMU is affected by diffuse faults confined within the NMU suggesting that the multilayered package responded to salt deformation as an overall brittle or brittle-ductile unit. This indicates that the NMU is characterized by a complex internal mechanical stratigraphy compared to the upper Plio-Quaternary deposits. Kartveit et al., (2019), made similar observations and interpreted these small faults confined to the NMU as being controlled by anhydrite-rich layers. Gvirtzman et al. (2017) also re-constructed the lithology of Unit 7 across the Israel Levant basin using well log data including Gamma and Resistivity logs, and pointed out the presence of alternating units of anhydrite, sand and clay layers, confirming the brittleductile nature of the Unit. Overall, the heterogeneity of the seismic facies, the internal erosive and dissolution features, and the multi-layered structural response to late deformation suggest that the NMU comprises a complex stratigraphy, including re-deposited units observed along basin flanks or the margins of salt structures that deformed the NMU and punctuated by dissolution events.

\subsection{Salinity Crisis Events of North-eastern Levant Basin}

Based on our observations combined with previous work, we propose a simple model to explain how the Messinian Salinity Crisis commenced and ended in the northeast Levant Basin, offshore Lebanon. 
Step 01: Around 5.97 My (following Meilijson et al., 2019) evaporite (halite) started to precipitate from hypersaline seawater in the deep Levant Basin (Meilijson et al., 2019). Marine conditions indicate that the western Mediterranean was connected to the Atlantic with open water exchange between the eastern and western Mediterranean Basins through the Sicily getaway (Güneş et al., 2018; Haq et al., 2020). At the same time, the Lower Gypsum Group (PLG) was deposited across marginal basins with carbonate development on platform areas (Fig. 18 a). In the Levantine basin this corresponds to the stage 1 of the MSC of Meilijson et al (2019).

Step 02: Thick accumulations of multicycle evaporites (Gvirtzman et al., 2017) were deposited in the deeper part of the Levant Basin (Figure 17b) with the $1^{\text {st }}$ gypsum cycle developed across marginal areas (Butler et al., 1995.) At this stage, the eastern Mediterranean is interpreted to be isolated from the western Mediterranean by the Sicily gateway (Camerlenghi et al., 2020; Güneş et al., 2018). This step corresponds to the latter part of stage 1 and stage 2 of the MSC (Meilijson et al., 2019). (Fig. 18 b).

Step 03: At the end of Phase 2 and the start of Phase 3 of the MSC (sensu Meilijson et al., 2019), the Northern Levant Basin became a marginal marine basin due to the continuous precipitation of salt and lowering of sea level. Marginal basin areas were subject to subaerial exposure due to either lowering of sea level or isostatic forces as proposed by Kirkham et al 2020 (Figure 7 of their paper). This corresponds to a period of extensive dissolution (Gvirtzman et al., 2017) coupled with marine regression and subareal exposure along the basin margin (Bertoni \& Cartwright, 2007), with wave action (Bache et al., 2012) which all contributed to the shape of the BNM- Base of Nahar Menashe Unit and equivalent to the Intra Messinian Unconformity Surface. This is also equivalent to the Messinian Unconformity in Sicily (Butler et al., 1995) or the Top Evaporite Unconformity recognized by Bertoni and Cartwright (2007). The previously deposited marginal gypsum and platform carbonates were subaerially exposed and karstified (Fig. 18 c) as illustrated by the circular and linear dissolution features and collapsed overburden on top of the Unit.

Step 04: After the formation of the dissolution surface recorded by the BNM, the NMU was deposited in a marginal marine or lacustrine setting (or redeposited) as a mixed package of evaporites, carbonates, and clastics. Coherent $(2 / 3$ cycles) and parallel seismic reflection pattern in the well preserved and undeformed NMU sections, clearly indicates the 
continuation of the evaporite depositional history. The close resemblance of the seismic signatures of the NMU with the lower units within the Halite along with the intense dissolution indicators within the top part of the NMU indicate that the unit consists of several redeposited packages probably characterized by basin centre evaporites, basin marginal gypsum, and platform carbonates with clastics derived from both the Lebanon Highlands and the Latakia Ridge all of which were deposited before incision associated with widespread drainage system development (Fig. 18d). This is equivalent to the upper MSC stage 3.1 (Meilijson et al.,2019). In this period the tectonic uplift registered in the slope may have triggered the initial salt flowing mechanism producing the first intrasalt deformation and redeposit of the NMU along the margin slope.

Step 05: Deposition of the NMU was terminated due to the final and maximum lowering of water level in the reduced and marginally dried up the eastern Mediterranean. In response to this base-level fall, an extensive southerly-directed drainage network was established across the entire study area. Incision occurred in the NMU leaving relict topographic highs with dissolution of NM deposits in other areas. This represents the final phase of the MSC (3.2) in the northeast Mediterranean. (Fig. 18 e). This event dramatically reshaped the NMU contributing to its laterally variable thickness and facies distribution.

Step 06: A rapid marine transgression reflooded the basin as the reconnection between the Atlantic and Mediterranean became established and produced parallel and horizontal (vertical stacking) to sub-horizontal (lateral stacking) seismic reflections within the valley and channel system. These units are here interpreted as the first expression of the Zanclean marine reflooding (Andreetto et al. 2021). Seismic reflections appear to onlap or drape against the eroded edges of the remnant blocks of Nahr Menashe stratigraphy or covering the interfluve areas. The geometry and reflection characteristics indicate that the topography was passively infilled (Fig. 18f) probably due to rapid flooding and/or marine transgression. The rapid flooding combined with the tectonic compression and gradual uplift since the Late Messinian caused salt-detached gravity gliding which triggered further salt flowage (Gvirtzman et al.,2013; Oppo et al., 2021). Salt flowage contributed to creating kinematicallylinked domains parallel to the basin margin, from the slope towards the basin centre: a) extensional, characterized by margin-parallel growth faults which affected the NMU and the post-NMU deposits; this is where we observe Facies 1 ; b) translational, with little or null 
deformation of the overburden (which is where the NMU is better expressed by facies 3 to 5; c) contractional, with widespread folding of both the salt and overburden which affect the NMU and develop facies 6 . The marine marker also forms an erosional surface (onlap or truncation of the lower reflections, Figs. 10 and 17) following the initial transgression. The age of this event is relatively constrained by its older stratigraphic relationship to the $1.8 \mathrm{Ma}$ event horizon mapped by (Kirkham et al., 2020) and interpolated through our seismic dataset

\section{Conclusion}

Interpreting high-resolution 3D seismic data and producing detailed mapping across the NMU we can unravel some depositional aspects which relate to the final stages of the MSC across the Lebanese region of the Levant Basin. The following results were obtained:

- Six seismic facies characterizing the NMU are documented which indicate that it represents a laterally complex redeposited and multilayer brittle-ductile unit.

- The internal architecture of some of the internal NMU reflections suggest it represents deposited or redeposited layered mixed clastics derived from both the Lebanon Highlands and the Latakia Ridge in a context of lacustrine or very shallow marine depositional system. The internal reflectivity indicates it represents a multi-layered evaporitic sequence characterized by alternating halite, basin marginal gypsum, and clastics derived from platform carbonate subunits. The lack of core or well log data prevents further testing of this hypothesis.

- A complex, north to south trending drainage system was incised into the top of the NMU. The Plio-Quaternary units above the TNM show a seismic facies expression of finely layered units onlapping or infilling the erosive features. These deposits are interpreted be primarily marine in origin, related to a rapid marine transgression which passively infilled the channel and the valley systems cut into the TNM. These units are interpreted as the first expression of Zanclean marine reflooding (Andreetto et al., 2021)

- Our analysis, suggests that the maximum base level during Messinian times did not drop below the level of the BNM. The drainage network was initiated after deposition 
and/or redeposition of the Nahr Menashe unit, recording erosional rather than deposition and was passively infilled by later marine transgression.

- Our seismic mapping questions the current understanding of the significance of the NMU. It cannot represent a fluvial deposit developed coevally with the erosive drainage system as mapped by Madof et al (2019). In contrast, the NMU represents a longer and stratigraphically more complex event as indicated by the laterally heterogeneous seismic facies which point to a shallow (perodically evaporative), water environment that developed during the lowstand event and affected the entire Levantine basins prior to subsequent drainage network development. This was followed by a rapid transgressive event that infilled the erosive network and then flooded the entire Lebanon offshore basin.

\section{Acknowledgements}

We gratefully acknowledge Ramadan Ghalayini, Wissam Chbat, and the Lebanese Petroleum Administration(LPA) for the provision of data without which this project would not have been possible.Schluberger for granting Petrel( academic licenses. S.M thanks to Bangabandhu Fellowship Trust Bangladesh for supporting his Ph.D. grant. We thank C.Gorini for the fruitful discussion during wring of this paper .

\section{References}

Andreetto,F. Aloisi,G., Raad,F. Heida,H., Flecker, R., Agiadi .K., Lofi, J. Blondel.,S, Bulian.,F. ,Camerlenghi,A., Caruso, A.,Ebner,R., Garcia -Cstellanos.,D., Gullier., V., Guibourdenche, L., Gvirtzman., Z., Houyle.,T.T.,Meijer., PT., Moneron.,J., Sierro.,F.J., Travan., G,. Tzevahirtzian,A., Vasiliev I.,, Krijgsman.,W. Freshening of the Meditteranean salt giant:controversies and certainties around the terminal (Upper Gypsum and Lago Mare) phases of the Messinian Salinity Crisis. Earth Science Review, 2016., 2021.

Bache, F., Popescu, S. M., Rabineau, M., Gorini, C., Suc, J. P., Clauzon, G., Olivet, J. L., Rubino, J. L., Melinte-Dobrinescu, M. C., Estrada, F., Londeix, L., Armijo, R., Meyer, B., Jolivet, L., Jouannic, G., Leroux, E., Aslanian, D., Reis, A. T. dos, Mocochain, L., ... Çakir, Z. (2012). A two-step process for the reflooding of the Mediterranean after the Messinian Salinity Crisis. Basin Research, 24(2), 125-153. https://doi.org/10.1111/j.13652117.2011.00521.x 
Bertoni, C., \& Cartwright, J. A. (2007). Major erosion at the end of the Messinian Salinity Crisis: Evidence from the Levant Basin, Eastern Mediterranean. Basin Research, 19(1), 1-18. https://doi.org/10.1111/j.1365-2117.2006.00309.x

Beydoun , Z. R. (1999). Evolution and development of the Levant (Dead Sea Rift) Transform System: a historical-chronological review of a structural controversy. http://sp.lyellcollection.org

Brown, A. R. (2004). Interpretation of Three-dimensional Seismic Data. American Association of Petroleum Geologists and the Society of Exploration Geophysicists.

Burberry, C. M., Jackson, C. A. L., \& Chandler, S. R. (2016). Seismic reflection imaging of karst in the Persian Gulf: Implications for the characterization of carbonate reservoirs. AAPG Bulletin, 100(10), 1561-1584. https://doi.org/10.1306/04151615115

Butler, R. W. H., Lickorish, W. H., Grasso, M., Pedley, H. M., \& Ramberti, L. (1995). Tectonics and sequence stratigraphy in Messinian basins, Sicily: Constraints on the initiation and termination of the Mediterranean salinity crisis. GSA Bulletin 107 (4): 425-439

Camerlenghi, A., del Ben, A., Hübscher, C., Forlin, E., Geletti, R., Brancatelli, G., Micallef, A., Saule, M., \& Facchin, L. (2020). Seismic markers of the Messinian salinity crisis in the deep Ionian Basin. Basin Research, 32(4), 716-738. https://doi.org/10.1111/bre.12392

Cartwright, J. A., \& Jackson, M. P. A. (2008). Initiation of gravitational collapse of an evaporite basin margin: The Messinian saline giant, Levant Basin, eastern Mediterranean. Bulletin of the Geological Society of America, 120(3-4), 399-413. https://doi.org/10.1130/B26081X.1

Cartwright, J., Jackson, M., Dooley, T., \& Higgins, S. (2012). Strain partitioning in gravity-driven shortening of a thick, multilayered evaporite sequence. Geological Society Special Publication, 363(1), 449-470. https://doi.org/10.1144/SP363.21

Cartwright, J., Stewart, S., \& Clark, J. (n.d.). Salt dissolution and salt-related deformation of the Forth Approaches Basin, UK North Sea. www.elsevier.com/locate/marpetgeo

Chiesi, M., de Waele, J., \& Forti, P. (2010). Origin and evolution of a salty gypsum/anhydrite karst spring: The case of Poiano (Northern Apennines, Italy). Hydrogeology Journal, 18(5), 1111-1124. https://doi.org/10.1007/s10040-010-0576-2

Chopra, S. , \& M. K. J. (2007). Seismic attributes for prospect identification and reservoir characterization. Society of Exploration Geophysicists and European Association of Geoscientists and Engineers.

Druckman, Y., Buchbinder, B., Martinotti, G. M., Siman Tov, R., \& Aharon B', P. (1995). The buried Afiq Canyon (eastern Mediterranean, Israel): a case study of a Tertiary submarine canyon exposed in Late Messinian times. In Marine Geology (Vol. 123).

Evans, S., \& Jackson, C. A. (2019). Intrasalt Structure and Strain Partitioning in Layered Evaporites: Insights from the Messinian Salt in the Eastern Mediterranean. 81st EAGE Conference and Exhibition 2019. https://doi.org/10.3997/2214-4609.201900911 
Feng, Y. E., Yankelzon, A., Steinberg, J., \& Reshef, M. (2016). Lithology and characteristics of the Messinian evaporite sequence of the deep Levant Basin, Eastern Mediterranean. Marine Geology, 376, 118-131. https://doi.org/10.1016/j.margeo.2016.04.004

Gardosh, M. A., \& Druckman, Y. (2005). Seismic stratigraphy, structure and tectonic evolution of the Levantine Basin, offshore Israel. http://sp.lyellcollection.org/

Gardosh, M. A., Garfunkel, Z., Druckman, Y., \& Buchbinder, B. (2010). Tethyan rifting in the Levant Region and its role in Early Mesozoic crustal evolution. Geological Society Special Publication, 341, 9-36. https://doi.org/10.1144/SP341.2

Garfunkel, Z. (1998). Constrains on the origin and history of the Eastern Mediterranean basin. In Tectonophysics (Vol. 298).

Ghalayini, Ramadan, Daniel, J. M., Homberg, C., Nader, F. H., \& Comstock, J. E. (2014). Impact of Cenozoic strike-slip tectonics on the evolution of the northern Levant Basin (offshore Lebanon). Tectonics, 33(11), 2121-2142. https://doi.org/10.1002/2014TC003574 2014

Ghalayini, R., Nader, F. H., Bou Daher, S., Hawie, N., \& Chbat, W. E. (2018). Petroleum Systems of Lebanon: an Update and Review. Journal of Petroleum Geology, 41(2), 189-214. https://doi.org/10.1111/jpg.12700

Gradmann, S., Hübscher, C., Ben-Avraham, Z., Gajewski, D., \& Netzeband, G. (2005). Salt tectonics off northern Israel. Marine and Petroleum Geology, 22(5), 597-611. https://doi.org/10.1016/j.marpetgeo.2005.02.001

Güneş, P., Aksu, A. E., \& Hall, J. (2018). Tectonic and sedimentary conditions necessary for the deposition of the Messinian evaporite successions in the eastern Mediterranean: A simple 2D model. Marine and Petroleum Geology, 96, 51-70. https://doi.org/10.1016/j.marpetgeo.2018.05.022

Gvirtzman, Z., Manzi, V., Calvo, R., Gavrieli, I., Gennari, R., Lugli, S., Reghizzi, M., \& Roveri, M. (2017). Intra-Messinian truncation surface in the Levant Basin explained by subaqueous dissolution. Geology, 45(10), 915-918. https://doi.org/10.1130/G39113.1

Gvirtzman, Zohar, Reshef, M., Buch-Leviatan, O., \& Ben-Avraham, Z. (2013). Intense salt deformation in the Levant Basin in the middle of the Messinian Salinity Crisis. Earth and Planetary Science Letters, 379, 108-119. https://doi.org/10.1016/j.epsl.2013.07.018

Gvirtzman, Zohar, Reshef, M., Buch-Leviatan, O., Groves-Gidney, G., Karcz, Z., Makovsky, Y., \& Ben-Avraham, Z. (2015). Bathymetry of the Levant basin: Interaction of salt-tectonics and surficial mass movements. Marine Geology, 360, 25-39. https://doi.org/10.1016/j.margeo.2014.12.001

Hall, J., Calon, T. J., Aksu, A. E., \& Meade, S. R. (2005). Structural evolution of the Latakia Ridge and Cyprus Basin at the front of the Cyprus Arc, Eastern Mediterranean Sea. Marine Geology, 221(1-4), 261-297. https://doi.org/10.1016/j.margeo.2005.03.007 
Haq, B., Gorini, C., Baur, J., Moneron, J., \& Rubino, J. L. (2020). Deep Mediterranean's Messinian evaporite giant: How much salt? Global and Planetary Change, 184. https://doi.org/10.1016/j.gloplacha.2019.103052

Hardage, B. A., Carr, D. L., Lancaster, D. E., Simmons, J. L., Elphick, R. Y., Pendleton, V. M., \& Johns, R. A. (1996). 3-D seismic evidence of the effects of carbonate karst collapse on overlying clastic stratigraphy and reservoir compartmentalization. GEOPHYSICS, 61(5), 1336-1350. https://doi.org/10.1190/1.1444057

Hardy, Homberg, C., Eyal, Y., Barrier, É., \& Müller, C. (2010). Tectonic evolution of the southern Levant margin since Mesozoic. Tectonophysics, 494(3-4), 211-225. https://doi.org/10.1016/j.tecto.2010.09.007

Hawie, N., Gorini, C., Deschamps, R., Nader, F. H., Montadert, L., Granjeon, D., \& Baudin, F. (2013). Tectono-stratigraphic evolution of the northern Levant Basin (offshore Lebanon). Marine and Petroleum Geology, 48, 392-410. https://doi.org/10.1016/j.marpetgeo.2013.08.004

Henderson, J., Purves, S. J., Fisher, G., \& Leppard, C. (2008). Delineation of geological elements from RGB color blending of seismic attribute volumes. The Leading Edge, 27(3), 342-350.

Hilton, V. C. ,. (2001). BG International offshore Israel, Med Yavne license: Or-1 \& Or South-1, Structural and sedimentological interpretation of STAR data, core sedimentology and petrography of core samples: Houston, Texas, Baker Atlas GEOScience, Final Report ZSL00-075.

Hsü, K. J., Ryan, W. B. F., \& Cita, M. B. (1973). Late Miocene desiccation of the Mediterranean. Nature, 242(5395), 240-244. https://doi.org/10.1038/242240a0

Jackson, M. P. A., Vendeville, B. C., \& Schultz-Ela, D. D. (1994). Structural Dynamics of Salt Systems . www.annualreviews.org

Jackson, M. P., \& Hudec, M. R. (2017). Salt tectonics: Principles and practice. Cambridge University Press.

Jaworska, J., \& Nowak, M. (2013). Anhydrites from gypsum cap-rock of Zechstein salt diapirs. Geology, Geophysics \& Environment, 39(3). https://doi.org/10.7494/geol.2013.39.3.233

Kartveit, K. H., Omosanya, K. O., Johansen, S. E., Eruteya, O. E., Reshef, M., \& Waldmann, N. D. (2018). Multiphase Structural Evolution and Geodynamic Implications of Messinian Salt-Related Structures, Levant Basin, Offshore Israel. Tectonics, 37(5). https://doi.org/10.1029/2017TC004794

Kartveit, Kyrre Heldal, Ulsund, H. B., \& Johansen, S. E. (2019). Evidence of sea level drawdown at the end of the Messinian salinity crisis and seismic investigation of the Nahr Menashe unit in the northern Levant Basin, offshore Lebanon. Basin Research, 31(5), 827-840. https://doi.org/10.1111/bre.12347 
Kirkham, C., Cartwright, J., Bertoni, C., Rodriguez, K., \& Hodgson, N. (2019). 3D kinematics of a thick salt layer during gravity-driven deformation. Marine and Petroleum Geology, 110, 434-449. https://doi.org/10.1016/j.marpetgeo.2019.07.036

Kirkham, Chris, Bertoni, C., Cartwright, J., Lensky, N. G., Sirota, I., Rodriguez, K., \& Hodgson, N. (2020). The demise of a 'salt giant' driven by uplift and thermal dissolution. Earth and Planetary Science Letters, 531. https://doi.org/10.1016/j.epsl.2019.115933

Kirkham, Christopher, Cartwright, J., Hermanrud, C., \& Jebsen, C. (2017). The spatial, temporal and volumetric analysis of a large mud volcano province within the Eastern Mediterranean. Marine and Petroleum Geology, 81, 1-16. https://doi.org/10.1016/j.marpetgeo.2016.12.026

Kyle, J. R., \& Posey, H. H. (1991). Halokinesis, Cap Rock Development, and Salt Dome Mineral Resources.

Lazar, M., Lang, G., \& Schattner, U. (2016). Coincidence or not? Interconnected gas/fluid migration and ocean-atmosphere oscillations in the Levant Basin. Geo-Marine Letters, 36(4), 293-306. https://doi.org/10.1007/s00367-016-0447-5

Lebedeva-Ivanova, N., Polteau, S., Bellwald, B., Planke, S., Berndt, C., \& Stokke, H. H. (2018). Toward one-meter resolution in 3D seismic. The Leading Edge, 37(11), 818-828.

Leila, M., Eslam, A., El-Magd, A.A. et al. Formation evaluation and reservoir characteristics of the Messinian Abu Madi sandstones in Faraskour Gas Field, onshore Nile Delta, Egypt. J Petrol Explor Prod Technol 11, 133-155 (2021). https://doi.org/10.1007/s13202-02001011-2

Lofi, J., Sage, F., Déverchère, J., Loncke, L., Maillard, A., Gaullier, V., Thinon, I., Gillet, H., Guennoc, P., \& Gorini, C. (2011). Refining our knowledge of the Messinian salinity crisis records in the offshore domain through multi-site seismic analysis. In Bull. Soc. géol. Fr (Vol. 182, Issue 2).

Madof, A. S., Bertoni, C., \& Lofi, J. (2019). Discovery of vast fluvial deposits provides evidence for drawdown during the late Miocene Messinian salinity crisis. Geology, 47(2), 171-174. https://doi.org/10.1130/G45873.1

Maillard, A., Hübscher, C., Benkhelil, J., \& Tahchi, E. (2011). Deformed Messinian markers in the Cyprus Arc: Tectonic and/or Messinian Salinity Crisis indicators? Basin Research, 23(2), 146-170. https://doi.org/10.1111/j.1365-2117.2010.00464.x

Matmon, A., Enzel, Y., Zilberman, E., \& Heimann, A. (1999). Late Pliocene and Pleistocene reversal of drainage systems in northern Israel: tectonic implications. In Geomorphology (Vol. 28).

Meilijson, A., Hilgen, F., Sepúlveda, J., Steinberg, J., Fairbank, V., Flecker, R., Waldmann, N. D., Spaulding, S. A., Bialik, O. M., Boudinot, F. G., Illner, P., \& Makovsky, Y. (2019). Chronology with a pinch of salt: Integrated stratigraphy of Messinian evaporites in the deep Eastern Mediterranean reveals long-lasting halite deposition during Atlantic 
connectivity. In Earth-Science Reviews (Vol. 194, pp. 374-398). Elsevier B.V. https://doi.org/10.1016/j.earscirev.2019.05.011

Micallef, A., Camerlenghi, A., Georgiopoulou, A., Garcia-Castellanos, D., Gutscher, M. A., lo Iacono, C., Huvenne, V. A. I., Mountjoy, J. J., Paull, C. K., le Bas, T., Spatola, D., Facchin, L., \& Accettella, D. (2019). Geomorphic evolution of the Malta Escarpment and implications for the Messinian evaporative drawdown in the eastern Mediterranean Sea. Geomorphology, 327, 264-283. https://doi.org/10.1016/j.geomorph.2018.11.012

Nader, F. H. (2011). The petroleum prospectivity of Lebanon: An overview. In Journal of Petroleum Geology (Vol. 34, Issue 2, pp. 135-156). https://doi.org/10.1111/j.17475457.2011.00498.x

Netzeband, G. L., Hübscher, C. P., \& Gajewski, D. (2006a). The structural evolution of the Messinian evaporites in the Levantine Basin. Marine Geology, 230(3-4), 249-273. https://doi.org/10.1016/j.margeo.2006.05.004

Netzeband, G. L., Hübscher, C. P., \& Gajewski, D. (2006b). The structural evolution of the Messinian evaporites in the Levantine Basin. Marine Geology, 230(3-4), 249-273. https://doi.org/10.1016/j.margeo.2006.05.004

Niyazi, Y., Eruteya, O. E., Omosanya, K. O., Harishidayat, D., Johansen, S. E., \& Waldmann, N. (2018). Seismic geomorphology of submarine channel-belt complexes in the Pliocene of the Levant Basin, offshore central Israel. Marine Geology, 403, 123-138. https://doi.org/10.1016/j.margeo.2018.05.007

Oppo, D., Evans, S., lacopini, D., Mainul Kabir, S. M., Maselli, V., \& Jackson, C. A.-L. (2020). Leaky salt: pipe trails record the history of cross-evaporite fluid escape in the northern Levant Basin, Eastern Mediterranean.

Petrolink, G., Brew, G., Barazangi, M., Al-Maleh, A. K., \& Sawaf, T. (2001). Tectonic and Geologic Evolution of Syria (Vol. 6, Issue 4). http://pubs.geoscienceworld.org/geoarabia/article-pdf/6/4/573/4560629/brew.pdf

Robertson, A. H. (1998). 54. Mesozoic-Tertiary Tectonic Evaluation of the Easternmost Mediterranean Area : Integration of Marine and Land Evidence 1 . In Scientific Results (Vol. 160).

Robertson, A. H. F., Parlak, O., \& Ustaömer, T. (2012). overview of the Palaeozoic - neogene evolution of neotethys in the Eastern Mediterranean region ( southern Turkey, Cyprus, Syria ). Petroleum Geoscience, 18(2004), 381-404. https://doi.org/10.1144/petgeo2011091.1354-0793/12/

Rodriguez, C. R., A-L Jackson, C., Bell, R. E., Rotevatn, A., \& Francis, M. (n.d.). Submarine salt dissolution in the Santos Basin, offshore.

Roveri, Marco, Flecker, R., Krijgsman, W., Lofi, J., Lugli, S., Manzi, V., Sierro, F. J., Bertini, A., Camerlenghi, A., de Lange, G., Govers, R., Hilgen, F. J., Hübscher, C., Meijer, P. T., \& Stoica, M. (2014). The Messinian Salinity Crisis: Past and future of a great challenge for 
Roveri, Marco, Gennari, R., Lugli, S., Manzi, V., Minelli, N., Reghizzi, M., Riva, A., Rossi, M. E., \& Schreiber, B. C. (2016). The Messinian salinity crisis: Open problems and possible implications for Mediterranean petroleum systems. Petroleum Geoscience, 22(4), 283290. https://doi.org/10.1144/petgeo2015-089

Roveri, M., Manzi, V., Bergamasco, A., Falcieri, F. M., Gennari, R., Lugli, S., \& Schreiber, B. C. (2014). Dense shelf water cascading and messinian canyons: A new scenario for the mediterranean salinity crisis. American Journal of Science, 314(3), 751-784. https://doi.org/10.2475/05.2014.03

Ryan, W. B. F. (1978). Messinian Badlands on the Southeastern Margin of the Mediterranean Sea *. In Marine Geology (Vol. 27).

Ryan, W. B. F., \& Cita, M. B. (1978). The Nature and Distribution of Messinian Erosional Surfaces - Indicators of a Several-Kilometer-Deep Mediterranean in the Miocene *. In Marine Geology (Vol. 27).

Ryan, W. B. F. , Hsu, K. J. , Cita, M. B. , Dumitrica, P. , Lort, J. , Maync, W. , Nesterhoff, W. D. , Pautot, G. , Stradner, H., \& Wezel, L. F. C. ,. (1973).. Initial Reports of the Deep Sea Drilling Project,13.

Stafford, K. W., Nance, R., Rosales-Lagarde, L., Boston, P. J., Stafford, K. W. ;, Nance, R. ;, Rosales-Lagarde, L. ;, Epigene, ", \& Manifestations, H. K. (2008). Repository Citation Repository Citation Epigene and Hypogene Gypsum Karst Manifestations of the Castile Formation:Eddy County, New Mexico and Culberson County, Texas, USA. https://scholarworks.sfasu.edu/geology/12

Vidal, N., Alvarez-Marrö N Ay, J., \& Klaeschen, D. (2000). Internal configuration of the Levantine Basin from seismic refection data (eastern Mediterranean). www.elsevier.com/locate/epsl

Zeng, H., Wang, G., Janson, X., Loucks, R., Xia, Y., Xu, L., \& Yuan, B. (2011). Characterizing seismic bright spots in deeply buried, Ordovician Paleokarst strata, Central Tabei uplift, Tarim Basin, Western China. Geophysics, 76(4). https://doi.org/10.1190/1.3581199

Zucker, E., Gvirtzman, Z., Granjeon, D, Garcia -Castellanos, D., Enzel, Y. (2021). The accretion of the Levant continental shelf alongside the Nile Delta by immense margin -parallel sediment transport. Marine and Petroleum Geology, 126.,2021

Zucker, E., Gvirtzman, Z., Steinberg, J., \& Enzel, Y. (2017). Diversion and morphology of submarine channels in response to regional slopes and localized salt tectonics, Levant Basin. Marine and Petroleum Geology, 81, 98111.https://doi.org/10.1016/j.marpetgeo.2017.01.002 


\begin{tabular}{|c|c|c|c|c|}
\hline Category & $\begin{array}{l}\text { External Shape } \\
\text { and } \\
\text { relationship to } \\
\text { salt }\end{array}$ & $\begin{array}{l}\text { Internal } \\
\text { reflection } \\
\text { characteristics }\end{array}$ & Occurrence & Interpretation \\
\hline $1 \mathrm{~A}$ & $\begin{array}{l}\text { Sheet, } \\
\text { conformable to } \\
\text { salt }\end{array}$ & $\begin{array}{l}\text { Parallel, } \\
\text { continuous, } \\
\text { Moderate to strong } \\
\text { Amplitudes , } 2 / 3 \\
\text { coherent cycles }\end{array}$ & $\begin{array}{l}\text { Bank of the } \\
\text { valley / channel } \\
\text { system, salt } \\
\text { triggered fold } \\
\text { valleys }\end{array}$ & $\begin{array}{l}\text { Remnant and } \\
\text { undisturbed blocks, } \\
\text { due to more confined } \\
\text { and incised valley } \\
\text { system, interpreted } \\
\text { as relic Islands }\end{array}$ \\
\hline $1 \mathrm{~B}$ & $\begin{array}{l}\text { Conformable to } \\
\text { rugged, Wedge }\end{array}$ & $\begin{array}{l}\text { Parallel, moderate } \\
\text { to strong, } 2 / 3 \\
\text { coherent cycles, } \\
\text { internally faulted }\end{array}$ & $\begin{array}{l}\text { Traced on } \\
\text { flanks of valleys } \\
\text { and salt diapirs } \\
\text { also in valley } \\
\text { banks }\end{array}$ & $\begin{array}{l}\text { Fractured and intra- } \\
\text { layered faulted, } \\
\text { clastic admixtures } \\
\text { made internal layers } \\
\text { more brittle, } \\
\text { dissolution surface } \\
\text { (lower boundary) } \\
\text { also cracked or } \\
\text { fractured }\end{array}$ \\
\hline $1 \mathrm{C}$ & Sheet & $\begin{array}{l}\text { mostly parallel, } \\
\text { faulted/fractured, } \\
\text { strong reflectors, } \\
\text { Coherent }(2 / 3 \\
\text { cycles), }\end{array}$ & $\begin{array}{l}\text { Present on dip- } \\
\text { slopes of tilted } \\
\text { fault block } \\
\text { crests }\end{array}$ & $\begin{array}{l}\text { Crestal fault created } \\
\text { mini basin, small } \\
\text { channel seen on } \\
\text { consecutive fault } \\
\text { breaking point }\end{array}$ \\
\hline 2 & $\begin{array}{l}\text { Mound } \\
\text { Occasionally } \\
\text { truncated with } \\
\text { intra-salt } \\
\text { stratigraphy }\end{array}$ & $\begin{array}{l}\text { semi-continuous, } \\
\text { mound shaped, } \\
\text { moderate to } \\
\text { weak reflection }\end{array}$ & $\begin{array}{l}\text { South western } \\
\text { part of the } \\
\text { valleys } \\
\text { associated } \\
\text { with sinkholes }\end{array}$ & $\begin{array}{l}\text { Brecciated karst } \\
\text { (salt/limestone),sub } \\
\text { aerially exposed at } \\
\text { the very last stage, } \\
\text { sink hole and fluid } \\
\text { pipe noticed on } \\
\text { lower boundary }\end{array}$ \\
\hline 3 & $\begin{array}{l}\text { Sheet } \\
\text { Downlapped }\end{array}$ & $\begin{array}{l}\text { Multi cycle, no } \\
\text { definitive internal } \\
\text { reflection, top } \\
\text { boundary is } \\
\text { difficult to trace } \\
\end{array}$ & $\begin{array}{l}\text { South } \\
\text { Weastern Part }\end{array}$ & $\begin{array}{l}\text { Dissolution coupled } \\
\text { with u/v shaped } \\
\text { channels and } \\
\text { fractured-internally } \\
\text { faulted }\end{array}$ \\
\hline 4 & $\begin{array}{l}\text { Sheet, } \\
\text { downlapped }\end{array}$ & $\begin{array}{l}\text { Multi cycle, no } \\
\text { definitive internal } \\
\text { reflection, top } \\
\text { boundary is } \\
\text { difficult to trace }\end{array}$ & $\begin{array}{l}\text { Central } \\
\text { northern Part }\end{array}$ & $\begin{array}{l}\text { Extensive } \\
\text { dissolution process } \\
\text { worked on lower } \\
\text { boundary, } \\
\text { sediments from } \\
\text { upper units drape } \\
\text { of collapsed into } \\
\text { the } \\
\text { accommodation }\end{array}$ \\
\hline
\end{tabular}




\begin{tabular}{|l|l|l|l|l|}
\hline 5 & Sheet drape & $\begin{array}{l}\text { Without internal } \\
\text { reflection, Low } \\
\text { amplitude, }\end{array}$ & towards NW & $\begin{array}{l}\text { Fine grained lithology } \\
\text { with somewhat } \\
\text { below seismic } \\
\text { resolution }\end{array}$ \\
\hline 6 & $\begin{array}{l}\text { Mound } \\
\text { Sub-parellel and } \\
\text { following dips } \\
\text { of intra-salt } \\
\text { stratigraphy }\end{array}$ & $\begin{array}{l}\text { Low to moderate } \\
\text { amplitude, } \\
\text { discontinuous, } \\
\text { subparallel to } \\
\text { wavy }\end{array}$ & $\begin{array}{l}\text { Both side of } \\
\text { the Latakia } \\
\text { Ridge, }\end{array}$ & $\begin{array}{l}\text { MTD followed } \\
\text { Latakia slopes }\end{array}$ \\
\hline
\end{tabular}

906

907

Figure Captions

908

909

Fig. 1 a. Location map of the study area showing topography, bathymetry and major structural elements. 2D seismic lines by blue line and 3D seismic cube by red box (used Petrel GIS service for map generation). The zoomed part indicates the 3D fence and embedded lines are the position of different seismic sections used in this paper. Bathymetry is derived by the 3D seismic data, GEBCO, and EDMOnet databases.

Fig. 1 b. Distribution of Messinian Evaporites in Mediterranean Basins and DSDP-ODP borehole locations (O ) which recovered Messinian Deposits ( source Roveri et al., 2014 ) . Study area.

Fig. 2 a. Seismic stratigraphy and chronostratigraphy of the Levant Basin modified after Krickham et al ., (2020), stratigraphic framework,nomenclatures and key markers are ( from Feng et al., 2016 and Gvirtzman et al., 2017) are correlated with chronostratigraphic models of Roveri et al., (2014b) and Meilijson et al., (2019), *TNM-Top Nahr Menashe, BNM-Bottom Nahr Menashe.

Fig. 2 b. Seismic markers of the study area with positive filling wiggle, as all the hard kicks associate with red colour trough so data displayed reverse polarity.

Fig. 3 Surface amplitude maps of three prominent seismic markers in the Levant Basin a) Sea bed b) BNM or IMTS, this is the surface that has imprinted dissolution features, impression of 
Fig. 04 Thickness map (twt) of the Nahr Menashe Unit in northeast Levant Basin, illustrates the distribution of the remnant blocks after dissolution and fluvial incision over this unit, numerous channels also invaded the top unit transversely .**Numerical values indicating the interpreted seismic facies distribution within Narh Menashe (Fig. 14)

Fig. 5 Attributes maps (time slice) on Nahr Menashe Unit showing the morphology and distribution of Channel / valley systems over the unit. Bottom of this Unit (BNM/IMTS) has been flattened for better understanding.

Fig. 6 Surface map of the Nahr Menashe Unit clearly shows the fluvial morphology over the this Unit, seismic profile i, ii \& iii illustrate the distribution of Nahr Menashe and interaction with the fluvial incision and erosion. In 6 ii illustrates the nesting of channels within valley , 6 iii has been marked with blue arrows how the TNM has been eroded as its not a continuous reflector rather varies with Top Messinian Units remnants.

Fig. 7 a) Circular and linear dissolution imprints on BNM , material draping onto the accommodation spaces, no channel or erosive valley related to it, b) $\square$ part on seismic section has zoomed and mapped \& c) Circular and linear dissolution features are randomly distributed on BNM surface and they are not interrelated.

Fig. 8 Surface amplitude map of Intra-Nahr Menashe reflections, every surface has the signature of intense dissolution, similar to Intra Messinian Truncation Surface.

Fig. 9 Dissolution features like circular ( sinkholes) depression, collapsed overburden (passive collapsing), residual mound on BNM surface and fluid pipes like fractures through Nahr Menashe.

Fig. 10 First regional marker (Pink seismic reflector) after the Messinian Crisis. After TNM the interpreted reflection basically demarks classic marine Plio-Qarartenary sequences from lower evaporites and transitional units.

Fig. 11 First regional marker (Pink) after TMN is also an erosional as lower reflections are clearly truncated against this surface.

Fig. 12 Thickness map (twt) between Top Nahr Menashe and Marine Marker. Blue arrow indicate valley or channel filling after marine transgression and white arrow indicate low thickness due to remnants (blocks) of Nahr Menashe, dotted white lines are axes the paleo 
956 drainage network over Nahr Menashe, sediment thickness is more over the base of erosional

957 drainage network rather sides.

958 Fig. 13 RMS amplitude maps of (a) Nahr Menashe, white arrows indicate higher amplitudes 959 inside the drainage net network from surroundings, and (b) Marine Transgression Deposits, 960 red arrows indicate lower amplitudes inside the drainage net network from surroundings.

961 Fig. 14 Seismic facies with in the Top Messinian Unit (Nahr Menashe) in the north eastern 962 Levant Basin.

963 Fig. 15 Random seismic profiles illustrate the perspective orientations of different intra964 evaporite layers with BNM /IMTS, they are generally having parallel relationship other than 965 deformed by salt flowage, overburden load or tectonics.

966 Fig. 16 Nahr Menashe has close resemblance with lower units rather above Plio-Quaternary 967 marine sediments.

968 Fig. 17 Numerous faults and fractures those originated and died with in the Nahr Menashe 969 Unit, signify more brittle material within this unit than lower.

970 Fig 18: a,b,c,d : Steps of Messinian Events in the NE Levant Basin.

971 Fig. 18 : e, f : Fluvial incision over Nahr Menashe Unit and Passively infilling after marine 972 transgressing, g : Seismic Expression 


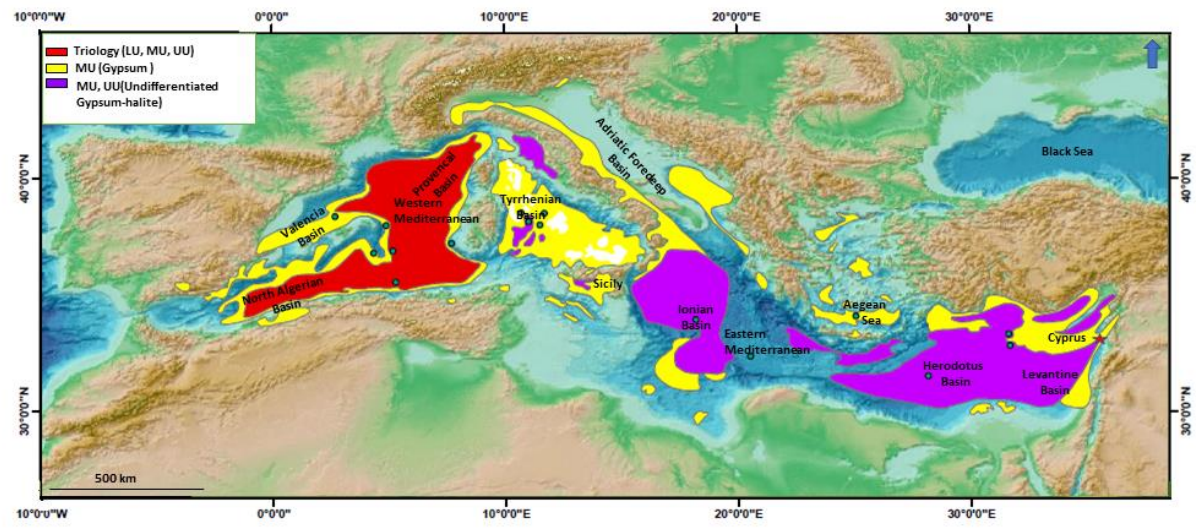

974

975

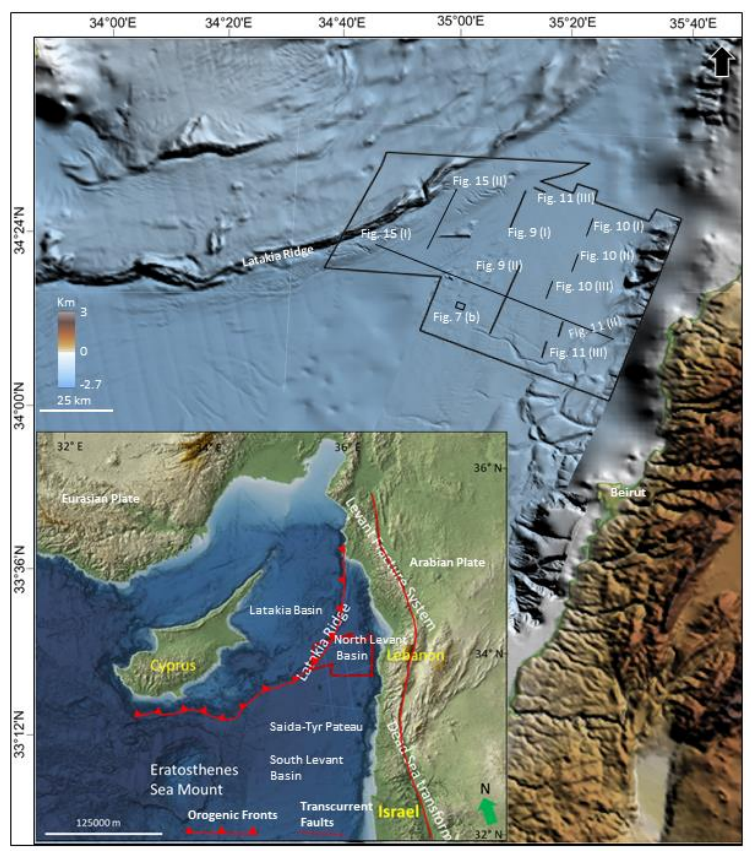



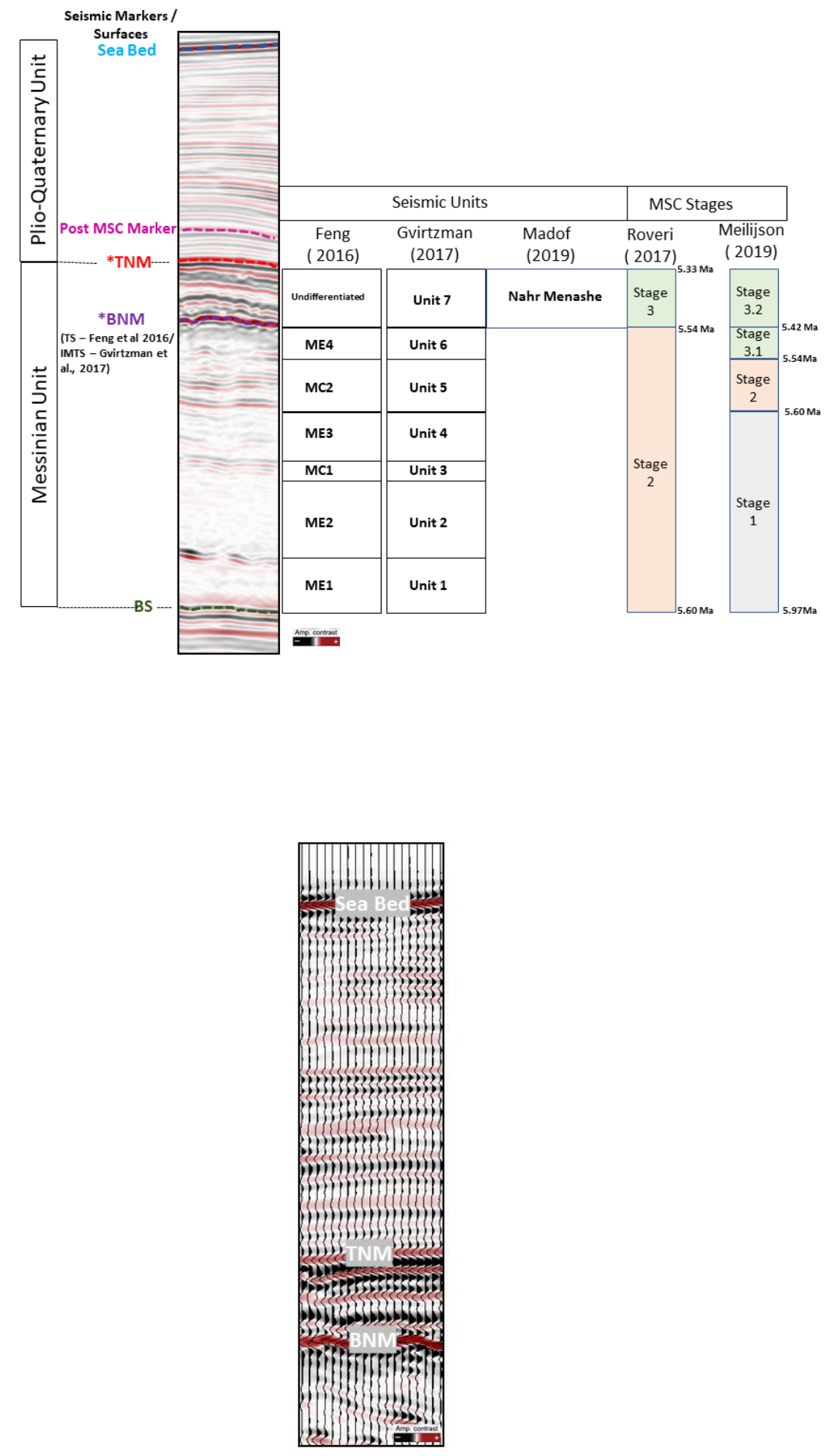

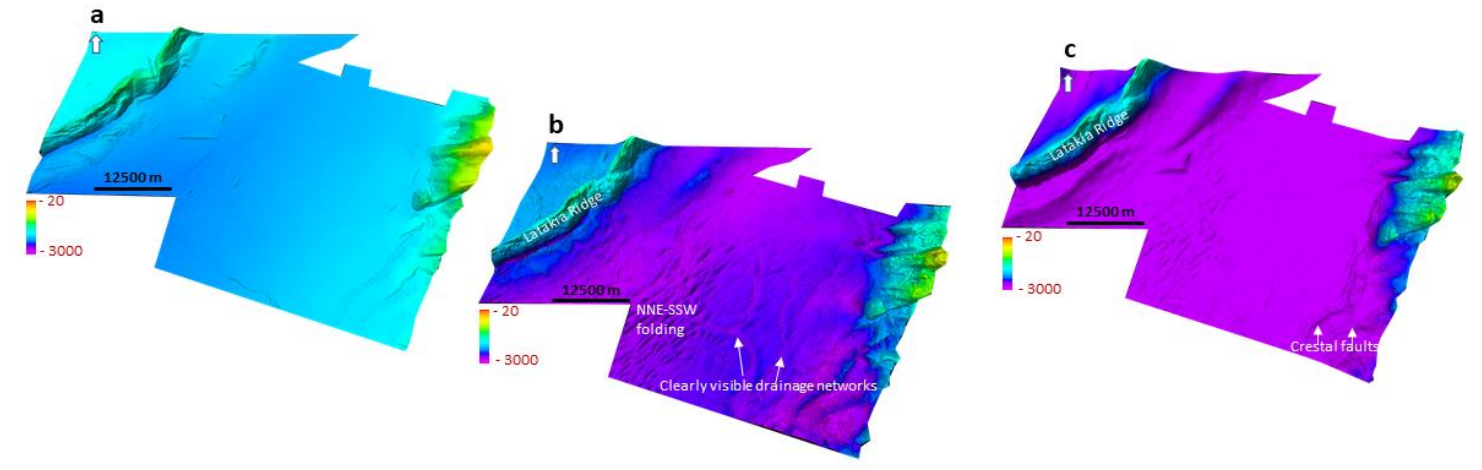

980

981

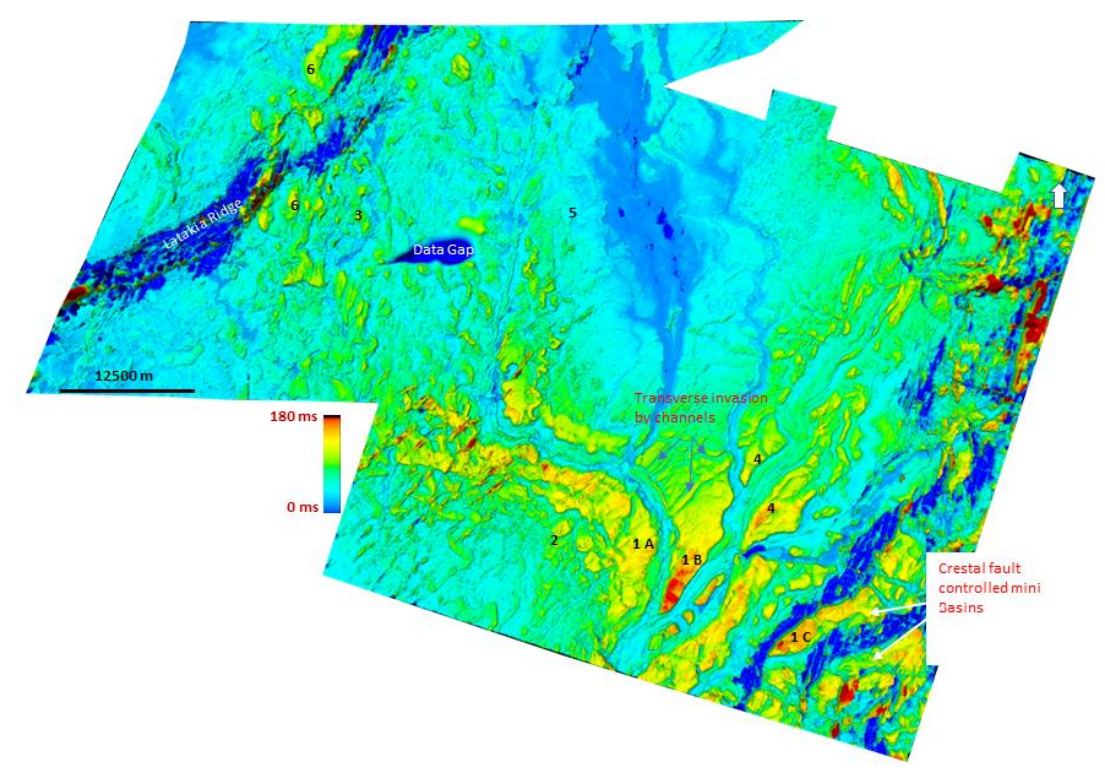

982

983 


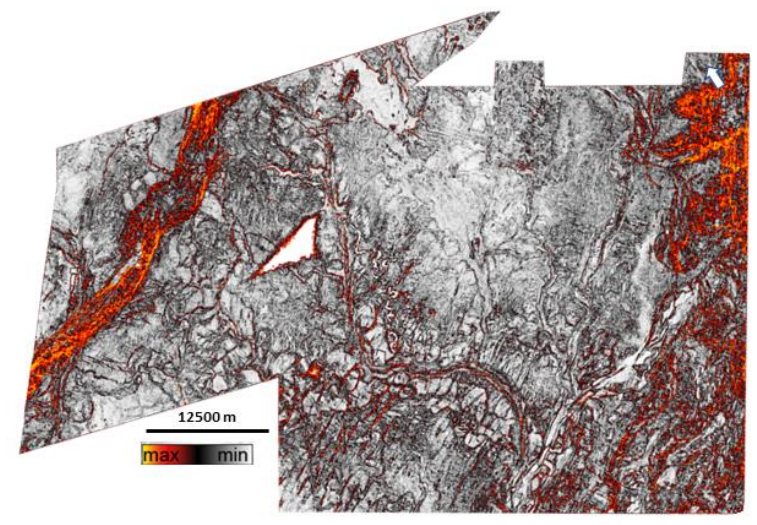

a) Variances attribute $Z=-2096 \mathrm{~ms}$ (twt)

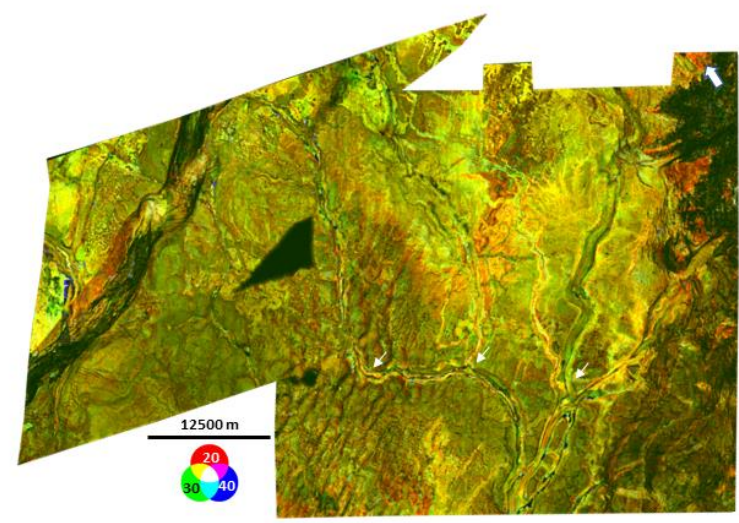

b) Generalized Spectral Decomposition, Mixer RGB, Inputs GSD $20 \mathrm{hz}, 30 \mathrm{hz}$ and $40 \mathrm{hz}$ $\mathrm{Z}=-2096 \mathrm{~ms}$ (twt)

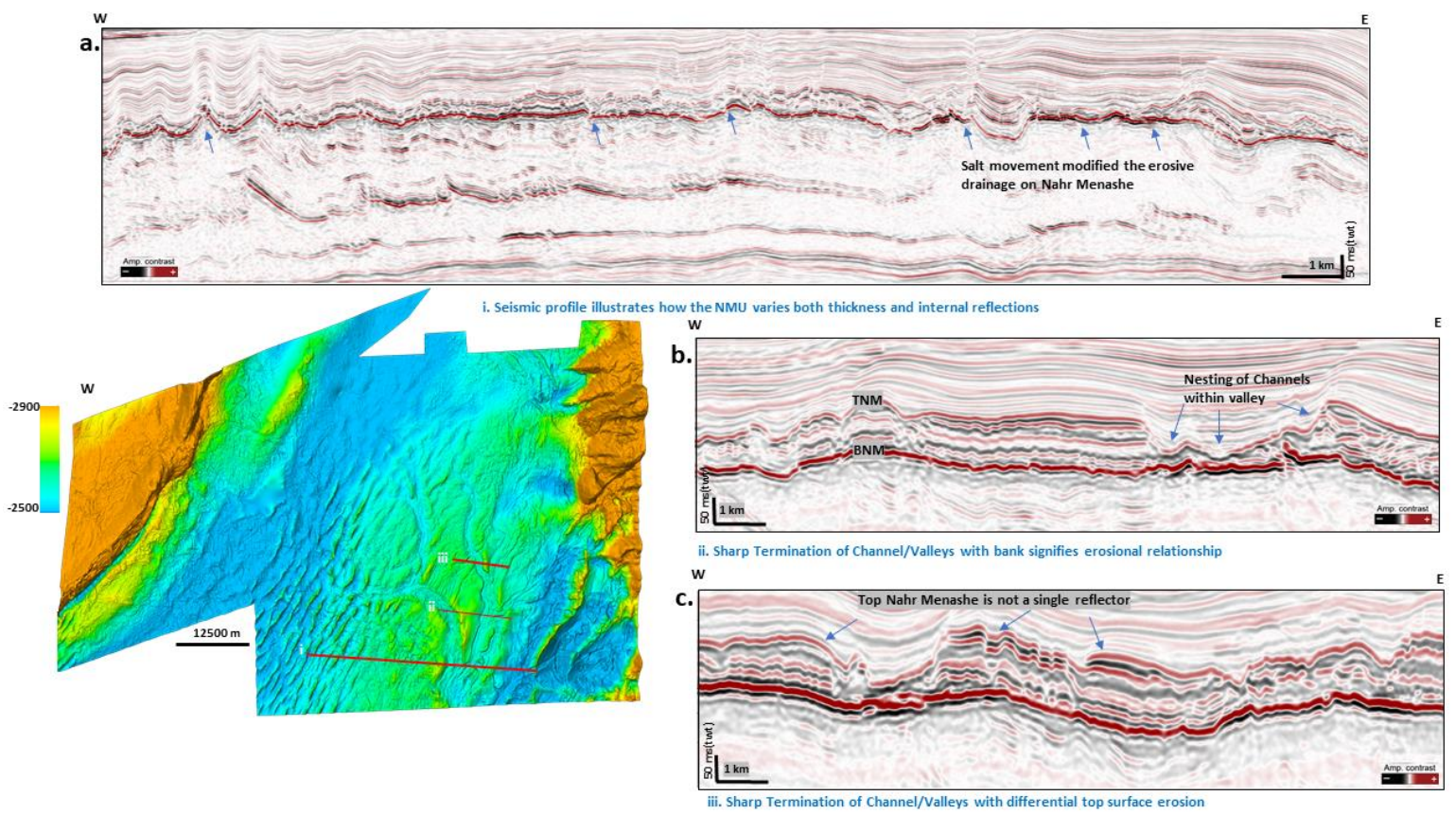



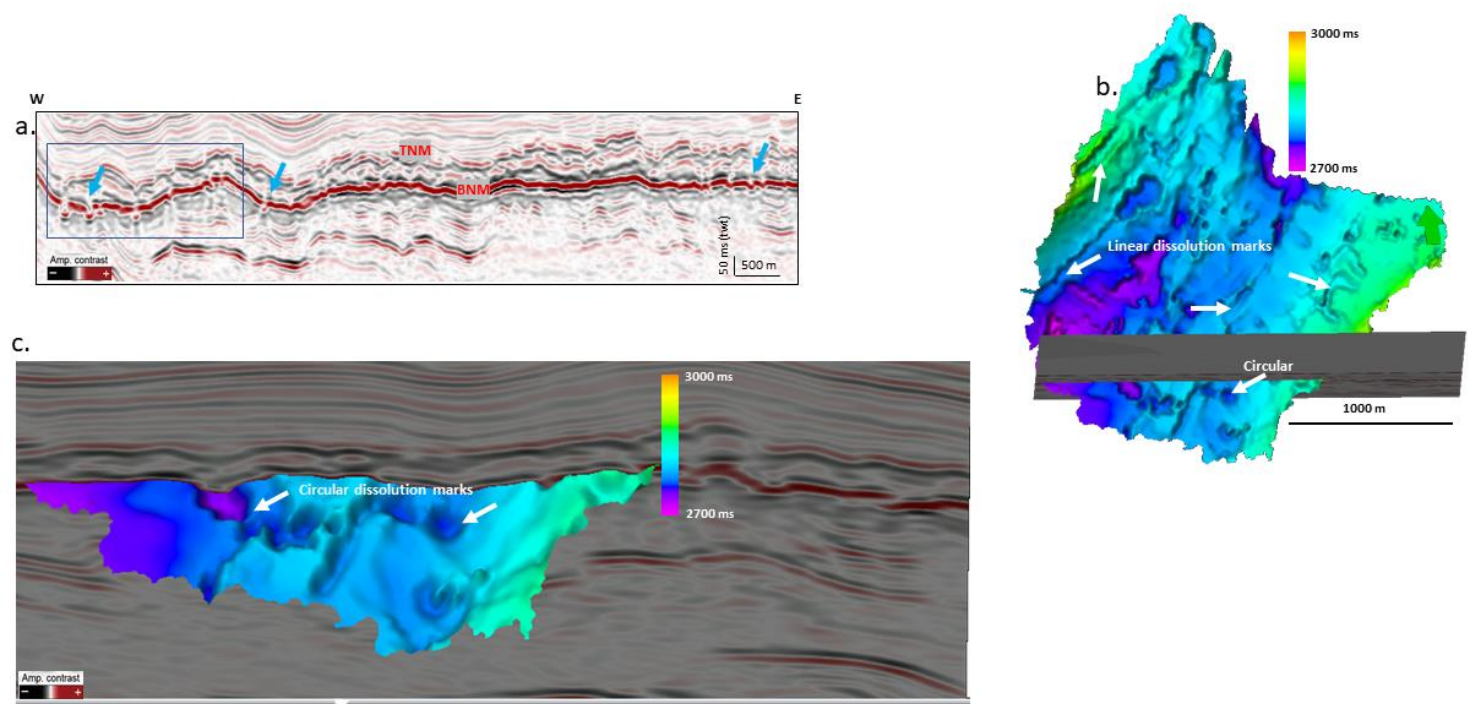

986

987

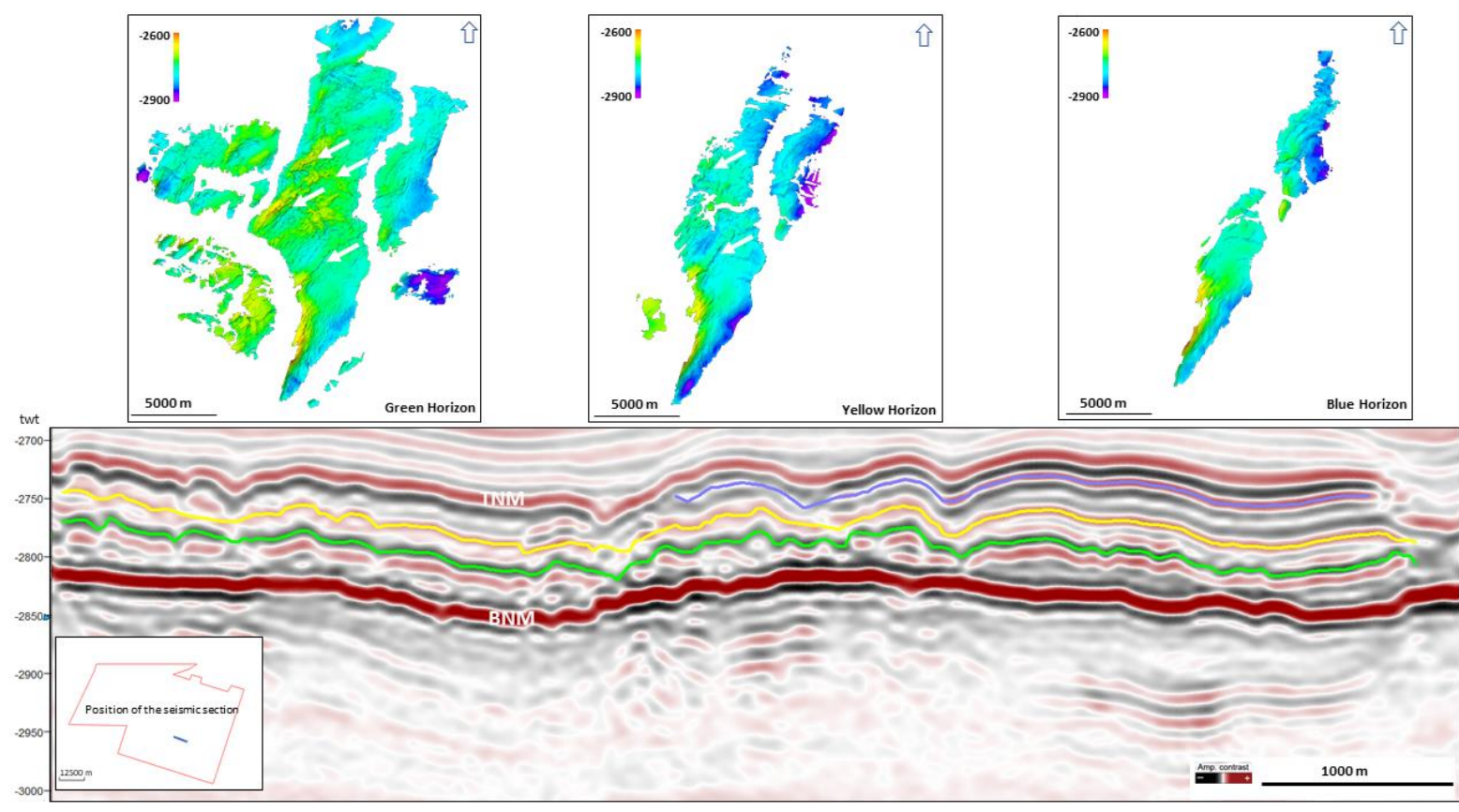



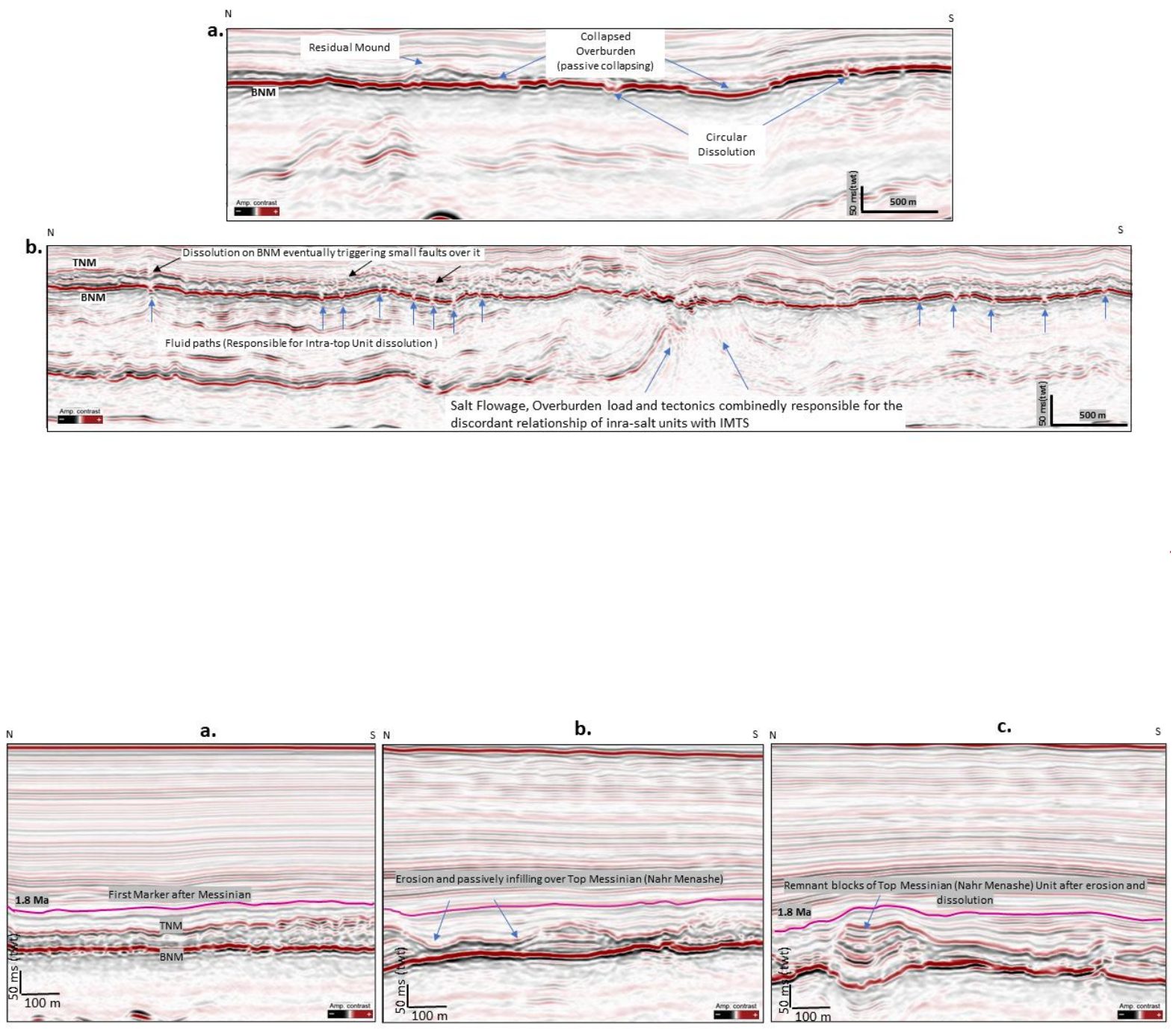

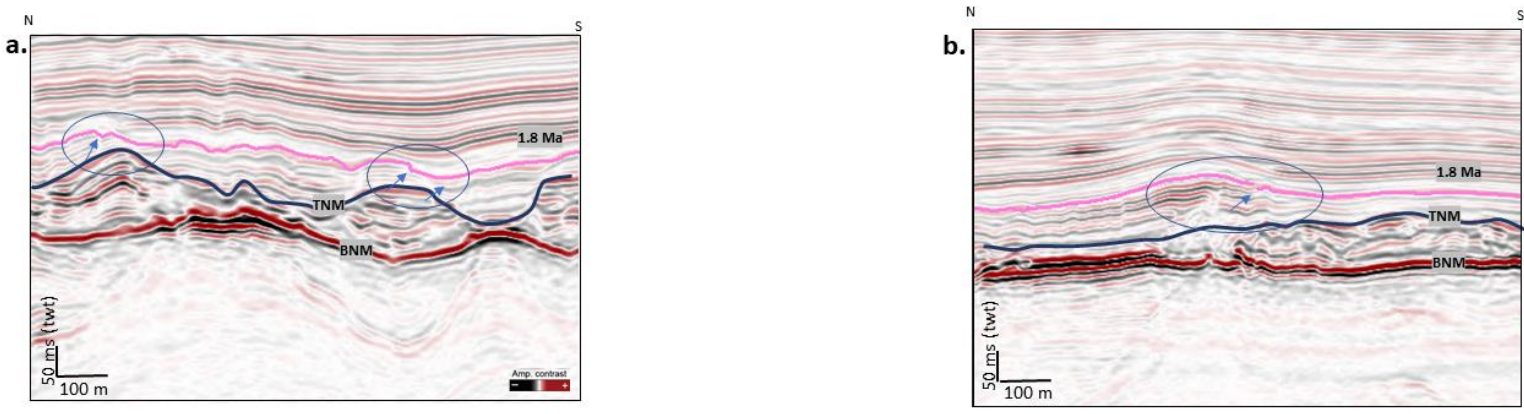

991

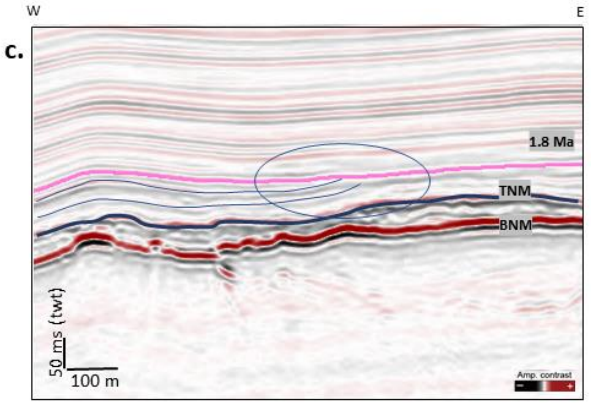

992

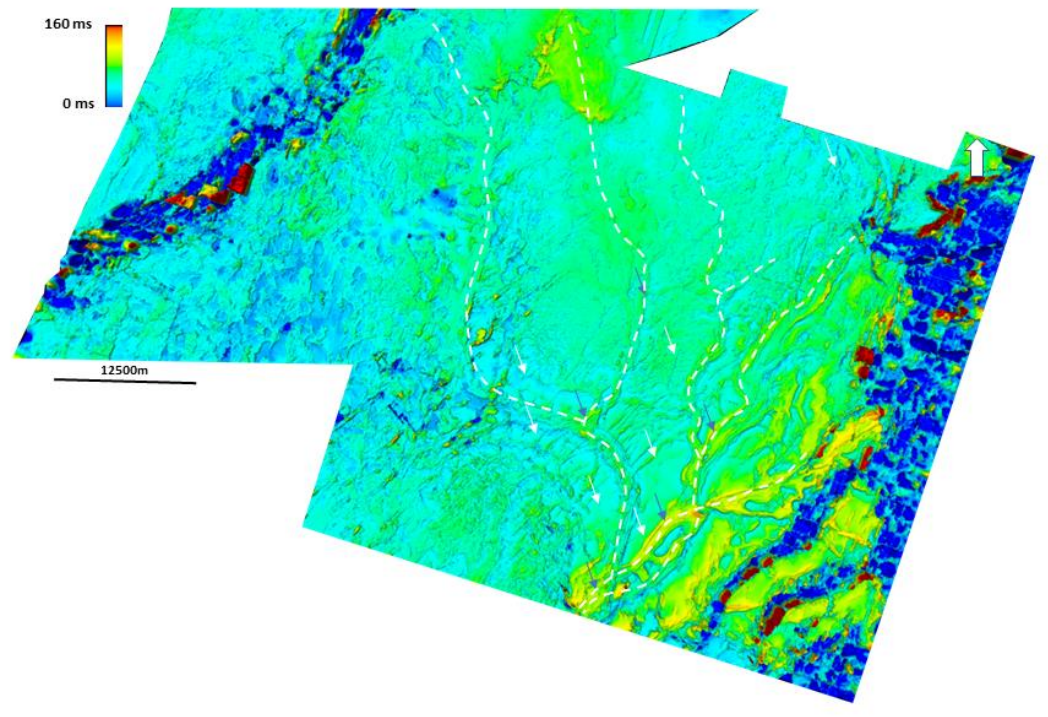




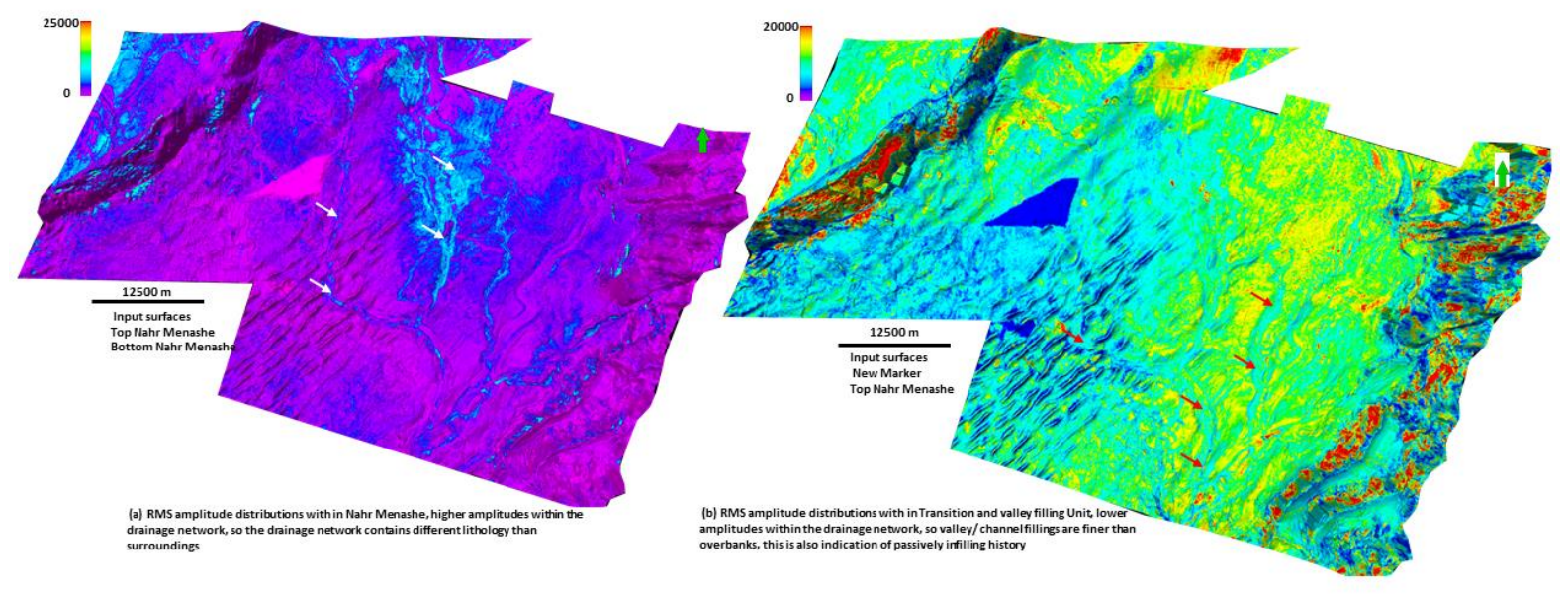

994

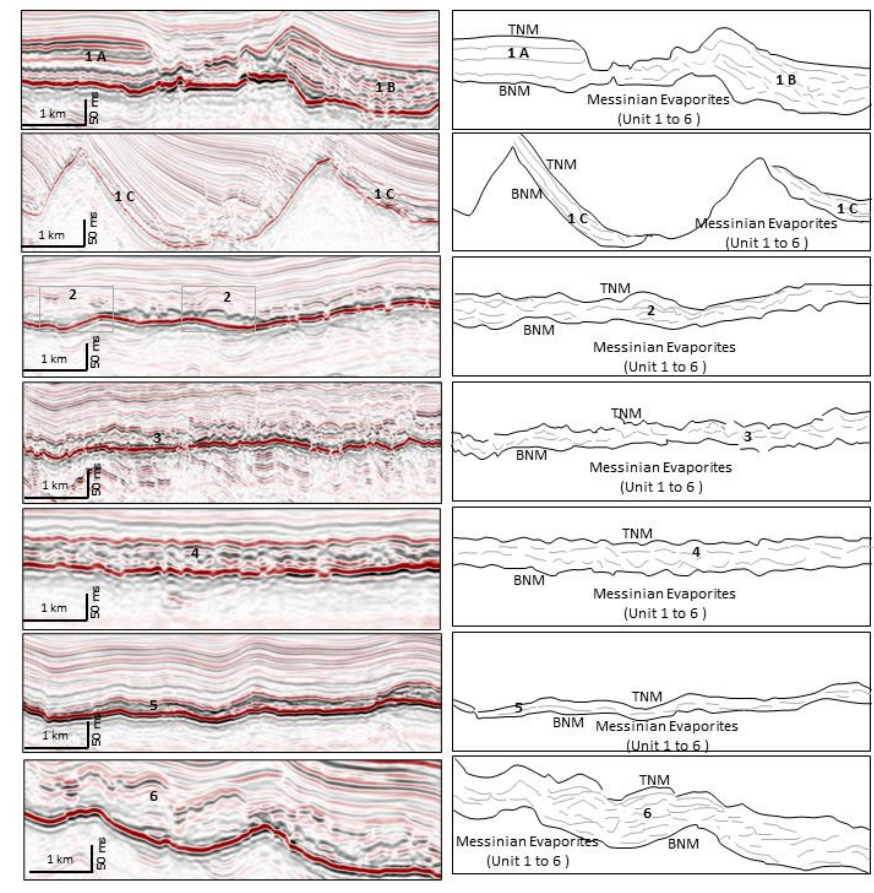


w

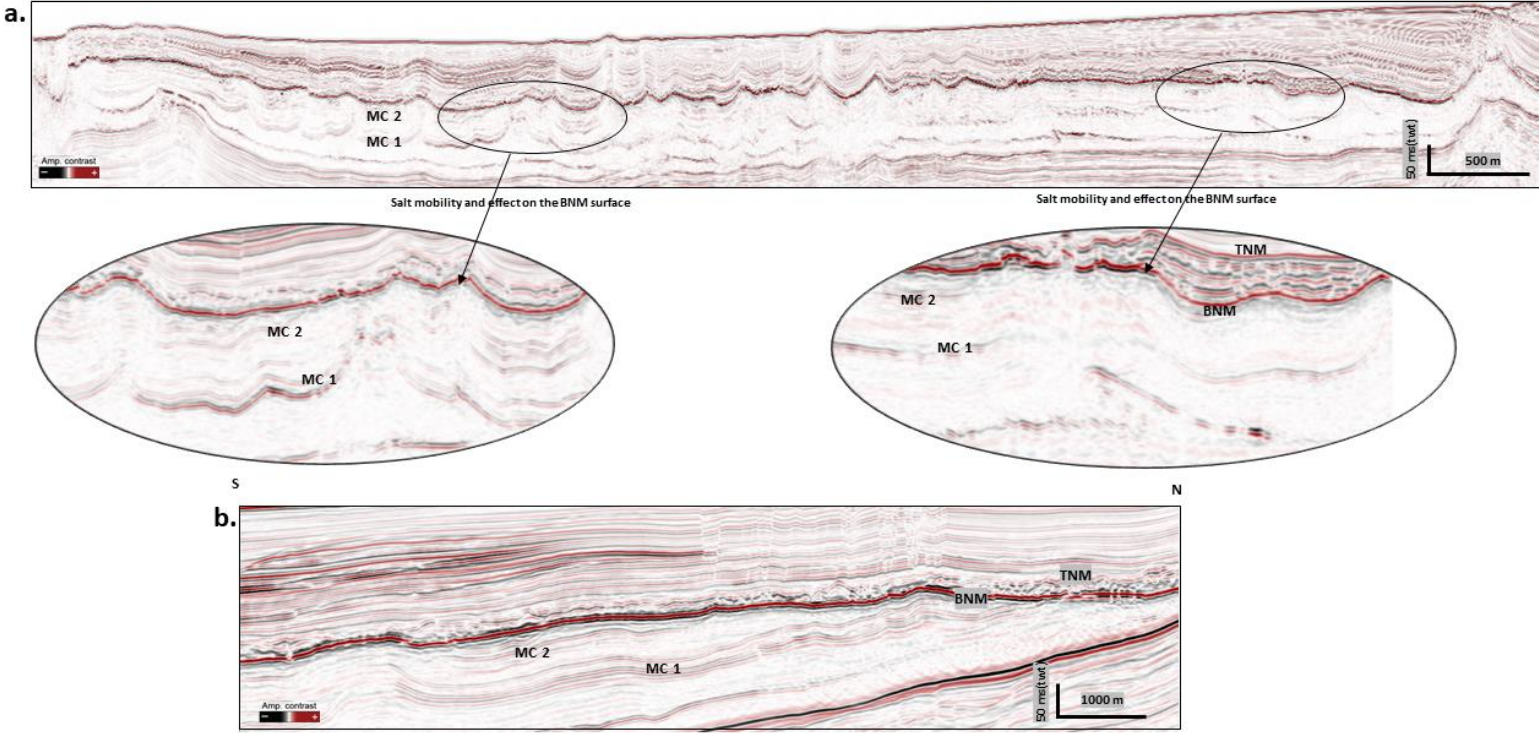

996

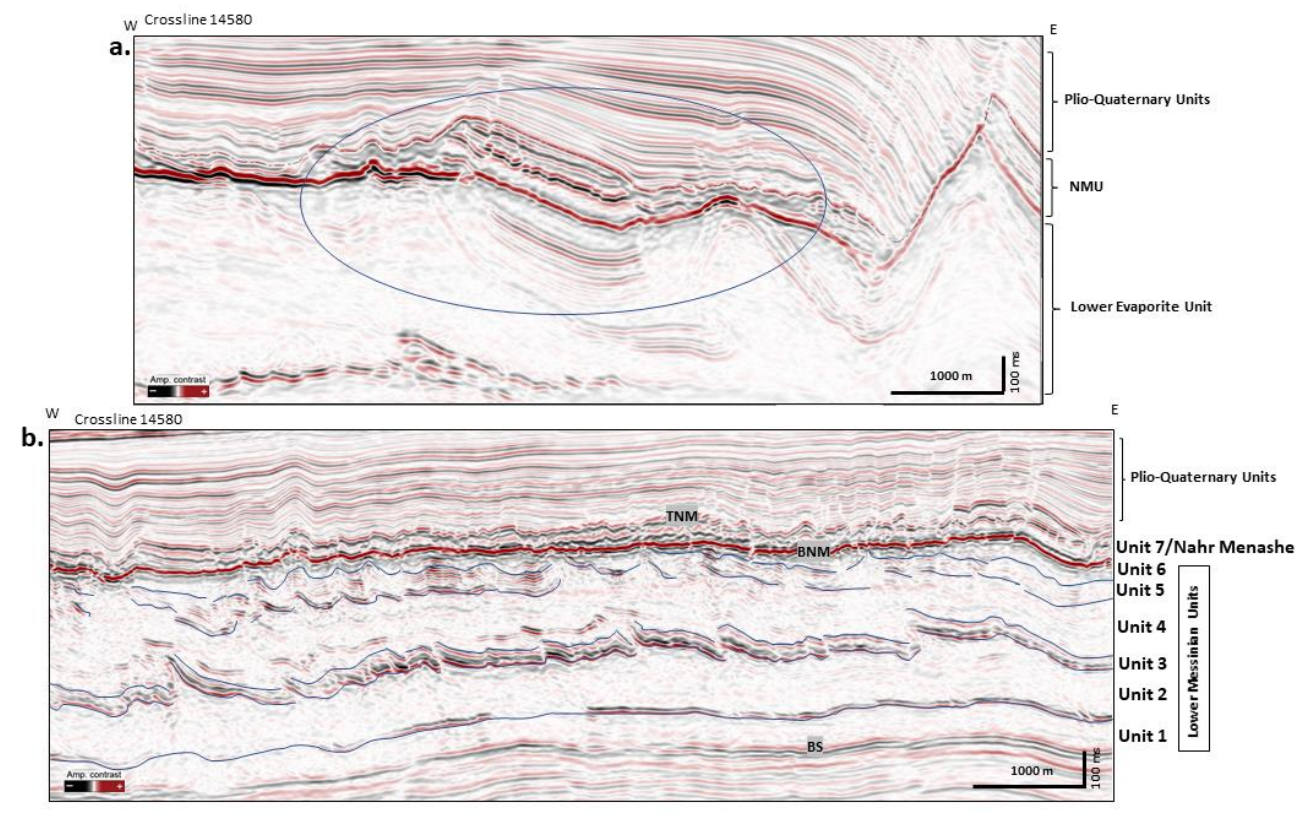

997

998 

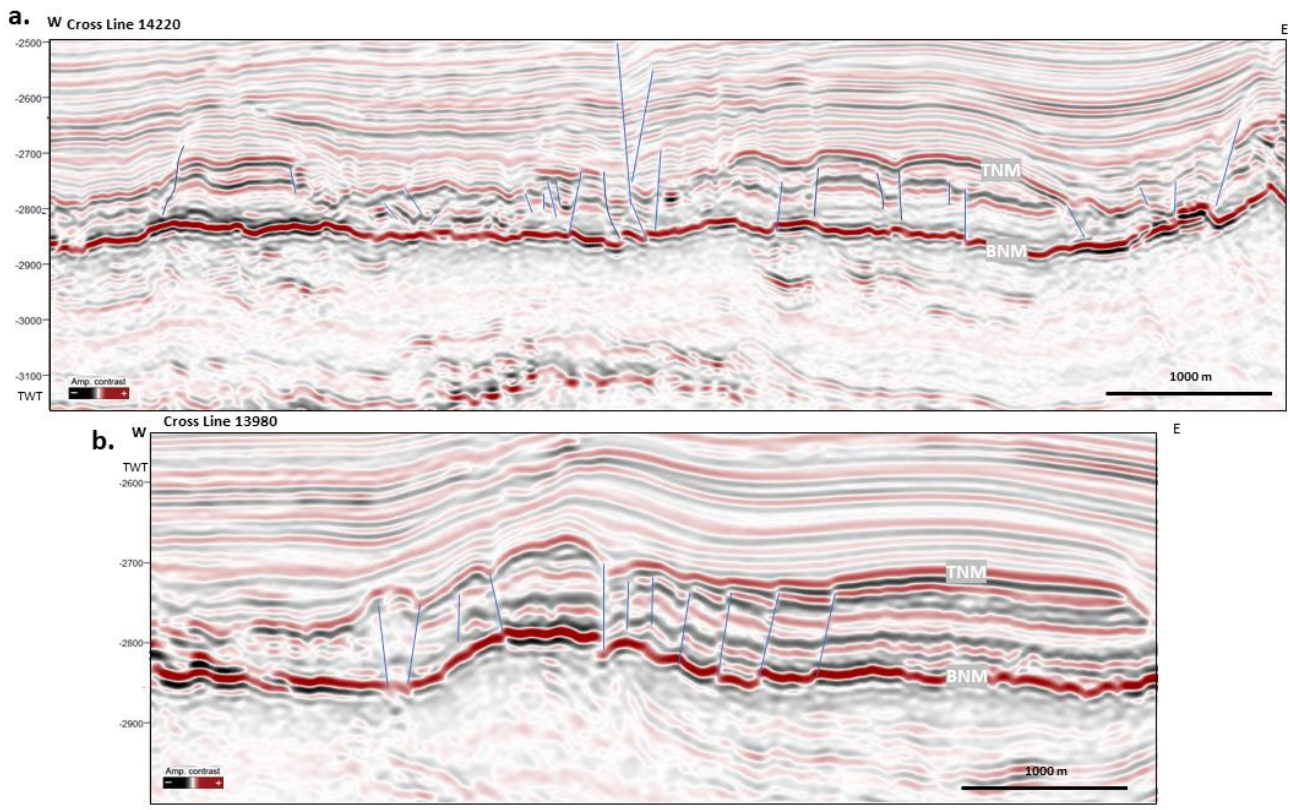

999

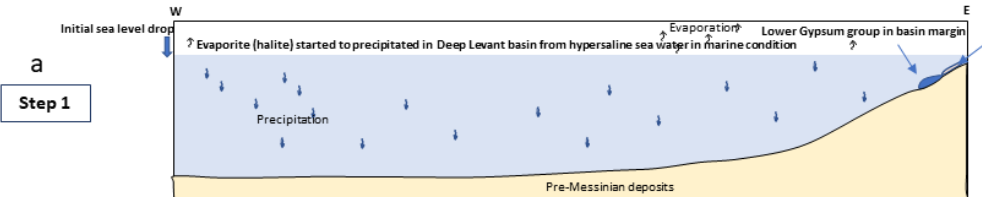

Initiation of Evaporite precipitation in the Levan asin in an open marine condition, $5.97 \mathrm{my}$

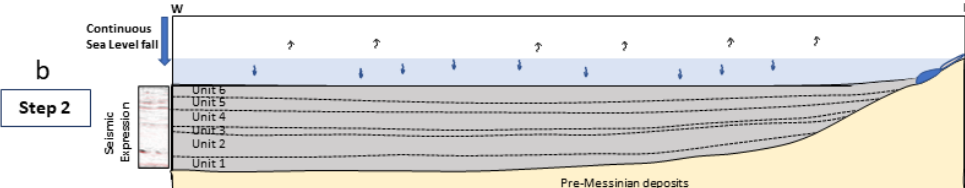

Thick column of multi cycle of evaporites

deposited in response to the Msc in the deeper

lowered, marginal and platform part were nearly above the sea level

c

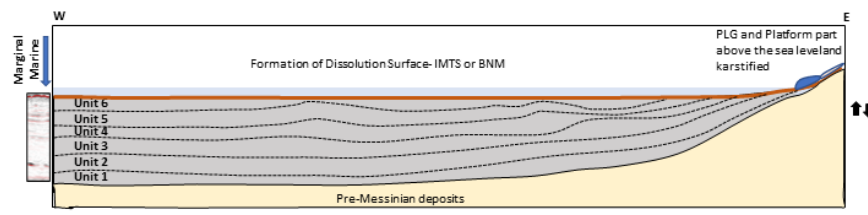

14 Initiation of land wise upliftment and basin differential gliding and spreading

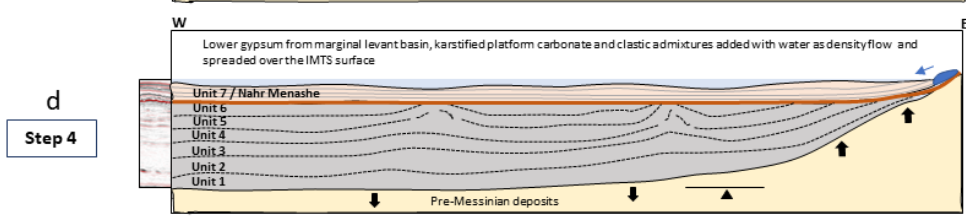

Nahr Menashe deposited/redeposited as a series of evaporite cycles as lacustrine or marginal marine marginal basin to the deeper part of the basin 


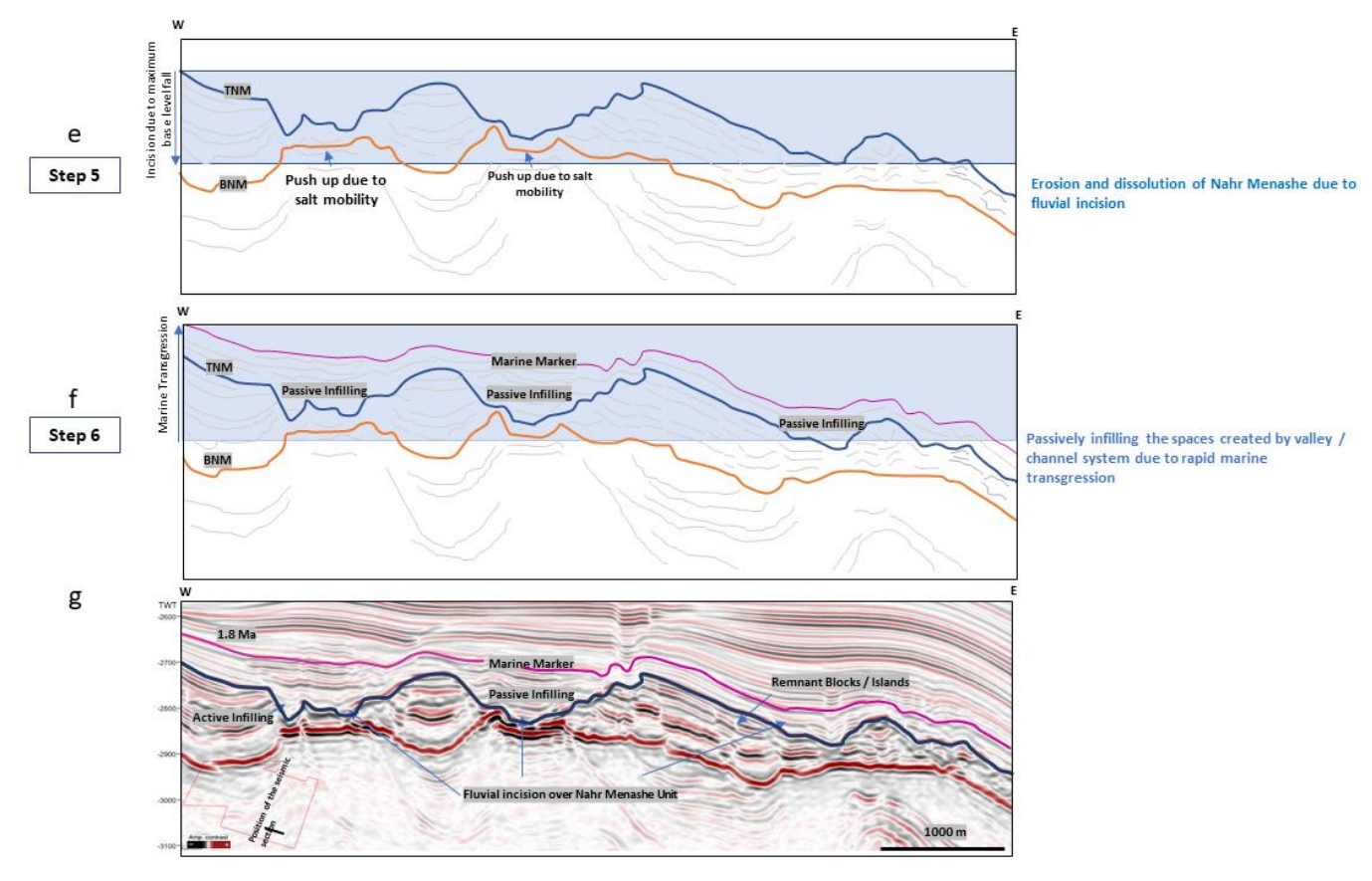

